\title{
Međuutjecaj klimatskih promjena i turističke djelatnosti - narativni pregled
}

IIIIIIIIIIIIIIIIIIIIIIIIIIIIIIIIIIIIIIIIIIIIIIIIIIIIIIIIIIIIIIIIIIIIIIIIIIIIIIIIIIIIIIIIIIIIIIIII

1 Aleksandar Racz

1 Zdravstveno veleučilište Zagreb

\section{Sažetak}

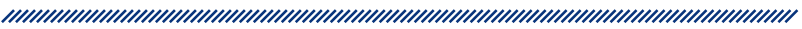

Turizam je jedna od najbrže rastućih globalnih gospodarskih aktivnosti te ima važnu ulogu u nacionalnim i lokalnim gospodarstvima. Globalne klimatske promjene, kao i održivi razvoj kroz društveno i ekološki odgovorno poslovanje u turizmu aktualno je područje istraživanja tek manjeg broja znanstvenika diljem svijeta. Nedostatak šireg interesa izostaje iako je ekspertna grupa okupljena oko Međunarodnog panela za klimatske promjene (IPCC) još sredinom drugog desetljeća 20. stoljeća potvrdila „S gotovo punom sigurnošću da ljudske djelatnosti dominantno uzrokuju globalno zatopljenje, koje dovodi do višestrukih manifestacija klimatskih promjena" te tako klimatske promjene prestaju biti tek predmet akademskog istraživanja, već su u ovom trenutku, uvažavajući i sve druge ekološke probleme, postale najveći izazov i prijetnja opstanku ljudske civilizacije, s brojnim posljedicama i vrlo širokim utjecajem na gotovo sve aspekte ljudskoga života, pri čemu nedvojbeno utječu i ekonomiju, socijalne aspekte i odnose u društvu, a tek jednim dijelom, iako vrlo važnim, i na turizam kao gospodarsku granu. Između turizma i klimatskih promjena postoji dvosmjerna međusobna veza. S jedne strane turizam uvelike ovisi o klimatskim elementima, na primjer temperaturi, padalinama $\mathrm{i}$ satima insolacije u danu, odnosno o klimi u cjelini kao važnom čimbeniku, a s druge strane turizam u cjelini, a posebice transport povezan s dolascima turista na destinacije i njihovim odlascima te turistički smještaj per se znatno pridonose globalnom zatopljenju kroz emisije stakleničkih plinova i znatni ugljikov otisak turističke djelatnosti. S obzirom na to da posljedice klimatskih promjena dovode, između ostalog, do povećanog rizika od poplava i suša, topljenja ledenjaka, povećanja razine mora, gubitka bioraznolikosti, raznih prijetnji ljudskom zdravlju, promjena odnosa u socijalnoj sferi, kao i s obzirom na to da nanose znatne štete svim ekonomskim djelatnostima, a istodobno uvažavajući iznimno visok doprinos turizma ukupnom bruto domaćem proizvodu nacionalnih ekonomija, svaki utjecaj klimatskih promjena na turizam može imati vrlo važne ekonomske i razvojne implikacije, posebice u $\mathrm{Hr}$ vatskoj, u kojoj turizam čini okosnicu gospodarstva. Ulažu se veliki napori na globalnoj i nacionalnoj razini u cilju ublažavanja posljedica klimatskih promjena te planiranju i poduzimanju mjera za sprječavanje daljnjih negativnih posljedica koje bi u budućnosti mogle biti nepopravljive. Ublažavanje međuutjecaja turizma i klimatskih promjena samo naizgled ovisi ponajprije o tehnološkim promjenama, već znatno ovisi i o ekonomskim, političkim, socijalnim i strukturnim promjenama.

Ključne riječi: klima, klimatske promjene, globalno zatopljenje, turizam, hoteli, globalno zagrijavanje

Datum primitka: 15.10.2019.

Datum prihvaćanja: 15.01.2020.

https://doi.org/10.24141/1/6/1/10

Adresa za dopisivanje:

Aleksandar Racz

Zdravstveno veleučilište Zagreb

E-mail: aleksandar.racz@zvu.hr

T: +385914595 722 


\section{Uvodno definiranje predmeta istraživanja s aspekta prirodnih $i$ društvenih znanosti}

Proučavanje klime i prirodnog okoliša u području ekonomskih znanosti, u polju turizma, važno je između ostalog i zato što su klima i okoliš temeljni resursi turizma, pri čemu su klima, turizam i okoliš neraskidivo povezani i međusobno uvjetovani. Ekspertna grupa okupljena oko Međunarodnog panela za klimatske promjene (IPCC) još sredinom drugog desetljeća 20. stoljeća potvrdila je „, gotovo punom sigurnošću da ljudske djelatnosti dominantno uzrokuju globalno zatopljenje, koje dovodi do višestrukih manifestacija klimatskih promjena" te tako klimatske promjene prestaju biti tek predmet akademskog istraživanja, već su u ovom trenutku, uvažavajući i sve druge ekološke probleme, postale najveći izazov i prijetnja opstanku ljudske civilizacije, s brojnim posljedicama i vrlo širokim utjecajem na gotovo sve aspekte ljudskoga života, pri čemu nedvojbeno utječu i ekonomiju, socijalne aspekte i odnose u društvu. ${ }^{1}$

\section{Definicije i podjele klime, klimatski elementi i klimatski faktori}

Klima ili podneblje nekog područja u nekom razdoblju definira se, prema Brankoviću, kao „skup usrednjenih ili očekivanih vrijednosti meteoroloških elemenata (varijabli) i pojava". ${ }^{2}$ Autor navodi da je grčki naziv (kasnolat.

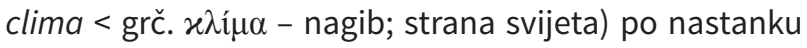
riječi povezan s:

„antičkim shvaćanjem načina na koji klima nastaje i razlikuje se od prostora do prostora unutar njima tada poznatog svijeta, a odnosilo se na zapažanje da Sunčeve zrake u različitim dijelovima svijeta upadaju pod različitim kutovima za što su ispravno zaključili da ovisi o geografskoj širini, pri čemu su Grci ispravno prepoznali povezanost zemljopisne širine i kuta upada zraka".

Suvremeni autori klimu definiraju klasičnom definicijom koja je opisuje kao „prosječni tijek vremena nad nekim mjestom ili područjem Zemljine površine u određenom razdoblju". ${ }^{3}$

Pod klimom kao meteorološkim pojmom smatra se „skup meteoroloških čimbenika i pojava koje u određenom periodu čine prosječno stanje atmosfere nad nekim dijelom Zemljine površine". Klima kao geografski pojam predstavlja skup atmosferskih stanja koja vladaju nad određenim dijelom Zemlje ili se definira i kao „prosječno stanje atmosfere nad određenim područjem/ima ili mjestom/ima u određenom definiranom razdoblju". ${ }^{4}$ Nadalje, klima kao biološki pojam smatra se i „kompleksom klimatskih uvjeta koji s drugim čimbenicima neke određene sredine određuju postojanje, razvitak, premještanje i razmnožavanje živih organizama". ${ }^{4}$

Klima ovisi o klimatskim elementima, koji se, prema nekim podjelama, mogu razvrstati u dvije grupe: prvu čine kozmički elementi, a drugu meteorološki elementi. Prema kozmičkim elementima, klima ovisi o izravnom zračenju, i to kako nebeskom ili difuznom zračenju tako i dugovalnom zračenju Zemlje. S druge strane, klima ovisi o meteorološkim elementima, dakle povezana je s temperaturom Zemlje, ali i zraka, tlakom zraka, smjerom i brzinom vjetrova, vlagom u zraku, koja ovisi i o isparavanju, kao i naoblakom koja direktno utječe i na trajanje sijanja sunca te nadalje i s oborinama i snježnim pokrivačem. ${ }^{3}$

Osim o klimatskim elementima, klima ovisi i o klimatskim faktorima, koji također mogu biti razvrstani u tri grupe. Prvu skupinu čine astronomski faktori, od kojih su najvažnije Zemljina rotacija i revolucija. Druga grupa faktora odnosi se na geografske, odnosno zemljopisne faktore. Konačno, treća grupa faktora naziva se i terestričkim faktorima, u koje se ubrajaju još Grcima poznata geografska širina, kao i raspored kopna i mora i tok kretanja morskih struja. Kroz terestričke faktore klima se povezuje i s atmosferom, reljefom, vrstama podloge na različitim nadmorskim visinama, primarno vodom, snijegom, ledom i kamenom, kao i s vrstama tla i biljnim pokrovom te dovodi u vezu s čovjekovom djelatnošću koja osim melioracije i pošumljavanja ima i svoje naličje kroz pustošenje. Budući da klimatski faktori neprekidno djeluju na klimatske elemente, nazivaju se i klimatskim modifikatorima. ${ }^{3}$

Ugrožavanje ravnoteže globalnoga ekološkog sustava i sve intenzivnije klimatske promjene jedne su od najvažnijih obilježja 20. stoljeća i prijelaza u novo tisućljeće. Važno je pritom naglasiti da „,promjenu klime nekog područja treba jasno razlikovati od varijacija unutar nekog klimatskog razdoblja koje se događaju unutar vrlo kratkih razdoblja, a posljedica su prirođene varijabilnosti i kaotičnih svojstava atmosfere".' O trajnoj promjeni klime govori se kada nastupi „znatna i trajna promjena u statističkoj razdiobi klimatskih elemenata i u razdoblju od nekoliko desetljeća". 
Klima dakle nije statična pojava i kroz vrijeme se mijenja, o čemu postoje brojni dokazi kroz dugu povijest postojanja Zemlje uz dokazano izmjenjivanje ledenih i međuledenih doba. Posljednje ledeno doba bilo je u razdoblju pleistocena, trajalo je tisućama godina, a završilo je prije oko 13000 godina. Za vrijeme toga ledenog doba oko $30 \%$ površine Zemlje bilo je prekriveno ledom. Sa stajališta fizike uzroke promjene klime dijelimo na prirodne i antropogene, pri čemu su prirodni uzroci varijacije u Sunčevu zračenju, orbiti Zemlje (astronomski uzroci), vulkanske erupcije i tektonski poremećaji, a antropogeni se vežu uz deforestaciju, potrošnju fosilnih goriva i posljedično ispuštanje $\mathrm{CO}_{2}$ i ostalih plinova u atmosferu, što dovodi do efekta staklenika i globalnog zatopljenja. Danas se razumije i zašto oblaci imaju velik utjecaj na klimu, budući da reflektiraju velik dio Sunčeva zračenja, a bez njih bi na Zemlji prosječna temperatura bila i za deset stupnjeva viša od sadašnje. Dugoročne promjene nagiba osi Zemljine rotacije te promjene njezinih orbitalnih parametara također dugoročno mogu uzrokovati globalne klimatske promjene, ali je riječ o iznimno sporim procesima.

Klima i klimatološki parametri i u Hrvatskoj variraju od godine do godine, ali kroz 20. stoljeće može se uočiti trend smanjenja padalina i trend porasta temperature na većini meteoroloških postaja u Hrvatskoj i tijekom većine godine. Razdoblje od 1999. do 2000. godine bilo je najtoplije razdoblje u Hrvatskoj u 20. stoljeću. Također je i relativno osunčavanje u razdoblju od 1971. do 2000 . godine bilo uglavnom od $0,5 \%$ do $2,1 \%$ veće nego u razdoblju od 1961. do 1999. godine. ${ }^{5}$ Međutim, daljnja mjerenja u prvoj dekadi 21 . stoljeća pokazala su da su devet od deset godina u toj dekadi bile ujedno najtoplije godine ako se do te točke promatrao cjelokupni period praćenja. ${ }^{6}$ Podaci za drugu dekadu 21 . stoljeća pokazali su daljnje zatopljenje te je četverogodišnje razdoblje od 2015. do 2018. godine ujedno najtoplije petogodišnje razdoblje od početka mjerenja.

S obzirom na to da trend promjena klime traje kroz cijelo 20. stoljeće, uočene klimatske promjene u drugom desetljeću 21. stoljeća predstavljaju jedan od najvećih izazova za čovječanstvo te su postale jedna od najozbiljnijih posljedica globalne okolišne krize i jedna od najvećih prijetnji opstanku života na Zemlji.

\section{Globalno zatopljenje - analiza recentnih trendova i parametara}

Znanstvena identifikacija antropogenih klimatskih promjena i procjene potencijalnih posljedica datiraju od prije nepunih 200 godina, kada je 1827. godine Fourier opisao učinak zagrijavanja zbog pojačanog efekta staklenika. Prije 120 godina, konkretno 1896. godine, Arrhenius je prvi izračunao učinak povećanja koncentracije ugljikova dioksida $\left(\mathrm{CO}_{2}\right)$ u atmosferi i predvidio da će udvostručenje $\mathrm{CO}_{2}$ dovesti do povećanja prosječnih globalnih temperatura od $5^{\circ} \mathrm{C}$ do $6{ }^{\circ} \mathrm{C}$, što je prilično blisko trenutačnim projekcijama, međutim, procijenio je „da će trebati još tri tisuće godina izgaranja fosilnih goriva kako bi se postiglo udvostručenje $\mathrm{CO}_{2}{ }^{\prime}{ }^{7}$

Brojni se autori slažu da klimatske promjene potječu iz prirode, „ali svoje uzroke imaju u ekonomskom, kulturnom i političkom sustavu koji se širi svijetom". "Većina vlada i znanstvenika diljem svijeta prepoznaje klimatske promjene „kao znatan društveni i ekološki problem s kojim se suočava globalna populacija i njezini resursi". ${ }^{9}$

Promjene globalne klime u zadnjih stotinjak godina vežu se uz promjene više elemenata klimatskog sustava, a prvenstveno uz promjene površinske temperature, visine razine mora i pokrivenost sjeverne hemisfere snijegom. Od 80-ih godina prošlog stoljeća prikuplja se sve više dokaza da ljudsko društvo presudno utječe na globalni okoliš, uslijed čega globalna temperatura raste, a kao posljedica antropogenog učinka klima se na planetu mijenja. Navedeno se uglavnom povezuje sa znatnim antropogenim doprinosim povezanim s intenzivnim sagorijevanjem fosilnih goriva nakon 1 . industrijske revolucije i otkrića parnog stroja te ulaskom rasta broja stanovnika na Zemlji u eksponencijalni dio krivulje. Širenje potrošnje materijala na bazi fosilnih goriva i promjena životnog stila glavni je pokretač globalnog korištenja resursima te glavni doprinos povećanju emisija stakleničkih plinova. ${ }^{10}$

Prema IPCC-u, globalno zatopljenje definirano je kao „povećanje kombinirane temperature zraka na površini tla i površini mora i tijekom 30-godišnjeg razdoblja", pri čemu se zatopljenje izražava u odnosu na razdoblje od 1850. do 1900. godine, koje se upotrebljava kao približna predindustrijska temperatura. ${ }^{11} \mathrm{U}$ skladu s time, zatopljenje od predindustrijskih razina do perioda između 2006. i 2015. godine procjenjuje se na $+0,87^{\circ} \mathrm{C}$ (vjerojatno između $+0,75^{\circ} \mathrm{C} i+0,99^{\circ} \mathrm{C}$. . Međutim, iz perspektive kraja drugog desetljeća 21 . stoljeća znanstvenici pretpostavljaju da je već u 2017. godini zatopljenje uzrokovano ljudskim djelovanjem dostiglo približno $1^{\circ} \mathrm{C}$ (vjerojatno između $+0,8^{\circ} \mathrm{C} \mathrm{i}+1,2^{\circ} \mathrm{C}$ ) iznad predindustrijskih razina uz vrlo zabrinjavajući rast za još $0,2^{\circ} \mathrm{C}$ (vjerojatno između $+0,1^{\circ} \mathrm{C} \mathrm{i}+0,3^{\circ} \mathrm{C}$ ) po desetljeću..$^{11}$ Zatopljenje veće od globalnog prosjeka već se dogodilo u mnogim regijama i sezonama, te 20 do $40 \%$ globalnog stanovništva živi u regijama koje su već u periodu između 2006. i 
2015. godine doživjele zatopljenje više od $1,5^{\circ} \mathrm{C}$ iznad predindustrijske razine, a kroz najmanje jednu sezonu. Zatopljenje veće od globalnoga godišnjeg prosjeka doživljava se u mnogim kopnenim regijama i godišnjim dobima, uključujući dva do tri puta više na Arktiku. ${ }^{11}$

Gledano s aspekta socijalnih i ekonomskih znanosti, stanovništvo najviše pogođeno klimatskim promjenama i globalnim zatopljenjem živi u zemljama niskog i srednjeg dohotka, od kojih su neke doživjele dodatan pad u npr. sigurnosti hrane, što je tek djelomično povezano $s$ rastom migracija i siromaštva. Mali otoci, megagradovi, obalna područja i visoki planinski lanci također su među najugroženijima zbog posljedica globalnog zatopljenja. ${ }^{12}$

Također su i proučavanja Svjetske meteorološke organizacije pokazala da se znakovit porast globalne temperature zraka pojavio od 1981. do 2010. godine. Porast globalne temperature u prosjeku je iznosio $0,17{ }^{\circ} \mathrm{C}$ po dekadi za vrijeme navedenog razdoblja, dok je za čitavo promatrano razdoblje od 1880 . do 2010 . godine prosječan porast iznosio $0,062{ }^{\circ} \mathrm{C}$ po dekadi. ${ }^{6} \mathrm{U}$ prvoj dekadi 21. stoljeća devet od deset godina bile su najtoplije godine ako se promatra čitav period praćenja. ${ }^{6}$ Podaci za drugu dekadu 21. stoljeća pokazali su da je daljnje zatopljenje i te kako moguće i realno.

U sedmom nacionalnom izvješću koje Hrvatska podnosi u skladu s odredbama i obvezama koje proizlaze iz Okvirne konvencije Ujedinjenih naroda o promjeni klime ${ }^{6}$ navodi se da je 2017. godina imala srednju globalnu godišnju temperaturu po vrijednosti rangiranu na trećem mjestu u kontinuitetu praćenja od predindustrijskog razdoblja, uz odstupanje od $+1,2{ }^{\circ} \mathrm{C}$ od prosjeka ako se uspoređuje s predindustrijskim razdobljem kojim smatramo period od 1881. do 1910. godine. Od deset najtoplijih godina od početka sustavnih meteoroloških mjerenja, devet su, osim 1998. godine, iz 21. stoljeća. ${ }^{6}$ Zadnje tri godine, dakle period između 2015. i 2017. godine, bile su tri najtoplije godine sa srednjom globalnom temperaturom za $1,1^{\circ} \mathrm{C}$ do $1,2^{\circ} \mathrm{C}$ iznad predindustrijskog razdoblja. U potpunosti se također 2018. godina uklopila u opisani trend. Posebno je zabrinjavajuće što je 2017. godina, usprkos tome što je bila godina bez utjecaja El Nina, bila godina jakog utjecaja ekstremnog vremena. ${ }^{6}$

\section{Uzroci globalnog zatopljenja - perspektiva znanosti o klimi vs. ekološki skepticizam}

Ekološki skepticizam, definiran kao sumnja u autentičnost ili ozbiljnost degradacije okoliša, uobičajen je za širu javnost. Međutim, u znanstvenoj literaturi postoji cijeli krug znanstvenika i radova u kojima se poriče postojanje klimatskih promjena ili se poriče antropogeni utjecaj na globalno zatopljenje i posljedične klimatske promjene. Björnberg i suradnici objavili su pregled više od 5000 članaka i analizu 161 znanstvenog rada objavljenih u više desetaka znanstvena časopisa indeksiranih u bazama Philosopher's Indeks, WoS i Scopus tijekom posljednjih 25 godina u cilju identificiranja nedostataka u tim istraživanjima i omogućavanja učenja na tom fenomenu poricanja koje se najviše usmjeravalo na klimatske promjene, s naglaskom na anglo-američke zemlje, gdje je ovaj oblik poricanja najčešći. ${ }^{13}$ Ostala pitanja zaštite okoliša i druga zemljopisna područja dobila su mnogo manje znanstvene pozornosti u znanstvenim člancima. Brojnost radova koji objavljuju znanstvene podatke, kao i raspon i visoka razina časopisa u kojima se objavljuju takvi radovi izazivaju bojazan da će se potaknuti organizirani napori za širenje sumnje u pouzdanost znanstvenih podataka i posljedično znatno odgoditi procese implementacije politike zaštite okoliša. Taj strah nije neosnovan, s obzirom na to da empirijske studije iz drugih političkih polja potvrđuju da organizirano poricanje znanosti koje su počinili akteri sa znatnim političkim ili ekonomskim kapitalom može utjecati na to kako društvo reagira na ozbiljne prijetnje ili probleme. Zbog toga je i analiza relevantnih radova važna radi pružanja odgovora na poricanje znanosti i stavljanje točke na njezin utjecaj na donošenje politike zaštite okoliša. Od ukupno analiziranih, oko $48 \%$ članaka ima angloameričku perspektivu i usredotočuje se na poricanje znanosti o okolišu i klimi u Njemačkoj, ${ }^{14}$ Australiji, ${ }^{15}$ Velikoj Britaniji ${ }^{16}$ i Sjedinjenim Američkim Državama. ${ }^{17}$

Druga grupa radova objavljena je u skandinavskim zemljama i odnosi se na istraživanja provedena u Švedskoj, ${ }^{18}$ Finskoj ${ }^{19}$ te Švicarskoj, ${ }^{20}$ Njemačkoj ${ }^{21,22}$ i Rusiji, ${ }^{23}$ kao i u zemljama poput Japana, ${ }^{24}$ Hong Konga ${ }^{25}$ ili Srbije. ${ }^{26}$ Oko četiri petine članaka odnose se na klimu, dok se ostali članci odnose na poricanje znanosti u drugim pitanjima okoliša ili na općenitijoj razini. ${ }^{27,} 28,29$ Poricanje znanosti o klimi daleko je najrasprostranjeniji oblik poricanja znanosti, što predstavlja okosnicu opozicije prema ekologiji i znanosti o okolišu, posebno u Sjedinjenim Američkim Državama, ali i u određenoj mjeri u Velikoj Britaniji i Australiji. Nekoliko je skupina poricatelja znanstvenih činjenica o klimatskim promjenama, pri čemu jedna grupacija osporava da je došlo do znatnijeg zagrijavanja, a drugi dovode u pitanje njegovu antropogenu prirodu, često je pripisujući Sunčevim aktivnostima, dok treća grupa skeptika prihvaća antropogene klimatske promjene, ali poriče da će imati znatne (ne- 
gativne) utjecaje na ljude ili okoliš, uz negiranje ili sumnju u postojeći konsenzus među klimatolozima o antropogenim uzrocima klimatskih promjena. ${ }^{13}$

Istraživanje na sličnu temu provela je i Whitmarsh, polazeći od pretpostavke da, iako se konsenzus znanstvene zajednice i političkih i medijskih poruka povezanih s realnošću globalnog zatopljenja i antropogeni doprinos kroz stakleničke plinove čine sve sigurnijima, stavovi i djelovanje javnosti prema tom pitanju ne slijede stavove većine znanstvene zajednice..$^{30}$ Naime, to potvrđuje i istraživanje Dorana i Zimmermana, koje je pokazalo da se $97 \%$ klimatologa slaže da ljudska aktivnost pridonosi klimatskim promjenama. ${ }^{31}$ Popularna i akademska rasprava često pretpostavlja da do negiranja dolazi zbog neznanja ili nerazumijevanja javnosti, ali neke studije sugeriraju da politička uvjerenja i vrijednosti mogu igrati važniju ulogu u određivanju vjerovanja u odnosu na skepticizam povezan s klimatskim promjenama.

U kontekstu klimatskih promjena na javni skepticizam i neizvjesnost mogu utjecati neslaganja stručnjaka, nesigurnost i vjerojatnosti temeljene na modelu. ${ }^{32}$ Rezultati su pokazali da je negiranje klimatskih promjena manje uobičajeno od percepcije da je to pitanje pretjerano, a utvrđeno je i da je skepticizam snažno određen ekološkim i političkim vrijednostima pojedinaca (posredno i po dobi, spolu, mjestu i načinu života), a ne obrazovanjem ili znanjem. Naime, rezultati su pokazali da oni ispitanici koji imaju politička stajališta desnog centra i niske proekološke vrijednosti imaju tendenciju biti najviše skeptični prema stvarnosti i ozbiljnosti klimatskih promjena. Drugim riječima, uvjerenja o klimatskim promjenama temeljno su povezana s postojećim vrijednostima i svjetonazorima. Više od toga, međutim, rezultati pokazuju da su percepcije vjerodostojnosti i značenja dokaza i pouzdanosti komunikatora informacija o klimatskim promjenama određene načinom na koji pojedinci gledaju na svijet i vrijednostima koje pridaju različitim ciljevima. Potvrđena je također teza koju je iznio Hulme da mnoga neslaganja o pitanju razmjera i uzroka klimatskih promjena odražavaju temeljne ideološke razlike u svjetonazoru i kao takve idu mnogo dalje od jednostavnog propitivanja znanstvene izvjesnosti ili dokaza. ${ }^{33}$ Također, nekoliko studija sugerira da su percepcije rizika više određene ideološkim varijacijama nego stručnošću. ${ }^{34}$ Zbog toga ne iznenađuju rezultati istraživanja prema kojima je tek samo manjina ispitanika u Velikoj Britaniji smatrala da klimatske promjene nisu antropogeno uzrokovane, ali i daleko više ispitanika izrazilo određenu razinu sumnje u stvarnost ili ozbiljnost problema. ${ }^{35} \mathrm{Na}$ primjer, prema istom istra- živanju 2006. godine $40 \%$ ispitanika iskazalo je stav da su klimatske promjene suviše složene i nesigurne za znanstvenike kako bi koristile prognoze te je čak $56 \%$ ispitanika smatralo da se mnogi vodeći stručnjaci još uvijek pitaju pridonosi li ljudska aktivnost klimatskim promjenama. ${ }^{35}$

U usporedbi s većinom drugih zemalja, čini se da je Velika Britanija posebno podijeljena u vezi s navedenim pitanjem, ${ }^{36}$ ali je i u SAD-u sumnja u stvarnost i ozbiljnost klimatskih promjena viša nego u Europi ${ }^{37}$ i povećavala se kroz vrijeme. Dio uočenog skepticizma mogao se objasniti postojanjem kognitivne disonance, psihološke pojave pri kojoj pojedinci teže prevladavanju nekonzistentnih stavova i ponašanja mijenjajući jedno ili drugo ili negirajući bilo kakav sukob. ${ }^{38} \mathrm{U}$ vezi s klimatskim promjenama, skeptičniji su načelno oni pojedinci koji bi trebali promijeniti svoj stil života kako bi pomogli u borbi protiv klimatskih promjena, ali pri tome doživljavaju znatne otpore. ${ }^{39}$ Prema tome, dio skepticizma o klimatskim promjenama može se protumačiti kao mehanizam poricanja ispitanika da se nose s unutarnjim neskladom na individualnoj razini između zahtjeva za uključivanje u klimatske promjene i stvarnog osobnog ponašanja. ${ }^{22}$ Važno je međutim jasno naglasiti da znanstvena zajednica hitno mora povećati svoje napore u demantiranju lažnih tvrdnji, otkrivanju shema kojima se služe osporavatelji i razvijanju djelotvornih i učinkovitih strategija za suzbijanje poricanja znanosti na svim razinama.

Globalno zatopljenje ima dugoročne kumulativne uzroke u odnosu modernog društva prema prirodi, a posljedice globalnog zatopljenja poput topljenja ledenjaka, podizanja razine mora i ekstremnih promjena vremena imaju ogroman utjecaj na čovječanstvo, okoliš te globalne i nacionalne ekonomije. ${ }^{40}$

Međutim, osim degradacije okoliša i zagađenje, mnoge regije i dalje karakterizira znatno siromaštvo i ozbiljna nejednakost u raspodjeli dohotka i pristupu resursima, što sve povećava osjetljivost na klimatske promjene. Neki bioetičari smatraju da je upravo zbog izrazitoga antropogenog doprinosa globalnom zatopljenju i svim posljedicama koje izaziva, nastanak čovjeka najveća greška evolucije.

Porast i povećanje globalnih temperatura za $0,5^{\circ} \mathrm{C}$ koje je Zemlja iskusila kroz proteklih 50 godina pridonio je pomacima u distribuciji biljnih i životinjskih vrsta, smanjenju prinosa i češćim požarima. Slične se promjene mogu očekivati s daljnjim porastom globalne temperature. Pretpostavka je da što je niži porast globalne temperature iznad predindustrijskih razina to su manji rizici 
za ljude, društva i prirodne ekosustave. Drugim riječima, ograničavanje zagrijavanja na $+1,5^{\circ} \mathrm{C}$ može se razumjeti u smislu tzv. „izbjegnutih utjecaja” u usporedbi s višim razinama zagrijavanja. ${ }^{11}$

Međunarodni panel za klimatske promjene 2014. godine iznio je stav da se „s gotovo punom sigurnošću potvrđuje da ljudske djelatnosti dominantno uzrokuju globalno zatopljenje, koje dovodi do višestrukih manifestacija klimatskih promjena". ${ }^{11}$

Dakle, danas uglavnom vlada suglasje u stavovima znanstvenika da su staklenički plinovi glavni antropogeni uzročnici klimatskih promjena povezanih s globalnim porastom temperature i globalnim zatopljenjem, ${ }^{41}$ iako pojedini skeptici i dalje dvoje oko uzroka globalnog zatopljenja, tvrdeći da je to „kombinacija periodičnih varijacija orbite Zemlje i njezine osi rotacije, kao i drugih prirodnih procesa". ${ }^{42}$ Većina znanstvenika polazi od činjenice da su se povećale globalne atmosferske koncentracije ugljikova dioksida $\left(\mathrm{CO}_{2}\right)$, metana i dušikova oksida izrazito kao rezultat ljudskih aktivnosti od 1750. godine i sada daleko premašuju predindustrijske vrijednosti. Sadašnje koncentracije stakleničkih plinova u atmosferi nezabilježene su u zadnjih 800000 godina. Globalno povećanje koncentracije $\mathrm{CO}_{2}$ prvenstveno je posljedica upotrebe fosilnih goriva i promjene u upotrebi zemljišta, dok je povećanje koncentracija metana i dušikova oksida prvenstveno posljedica poljoprivrede. Globalna koncentracija $\mathrm{CO}_{2} \mathrm{u}$ atmosferi porasla je s predindustrijske vrijednosti od oko 280 ppm na 379 ppm 2005. godine na temelju određivanja vrijednosti iz jezgre leda. Godišnja stopa rasta koncentracije $\mathrm{CO}_{2}$ bila je veća tijekom 10 godina na prijelazu tisućljeća (prosjek za period od 1995. do 2005. godine - 1,9 ppm godišnje) nego što je bila od početka kontinuiranih izravnih atmosferskih mjerenja (prosječno 1960. - 2005.: 1,4 ppm godišnje), iako nedvojbeno postoji godišnja varijabilnost stope rasta. Globalna koncentracija metana u atmosferi povećala se s predindustrijske vrijednosti od oko 715 ppm na 1732 ppm početkom 1990-ih te na 1774 ppb 2005. godine. Atmosferska koncentracija metana u 2005. godini daleko je nadmašivala prirodni raspon posljednjih 650000 godina (320 - 790 ppb). Globalna koncentracija dušikova oksida u atmosferi povećala se s predindustrijske vrijednosti od oko 270 ppm na 319 ppm 2005. godine. Stopa rasta približno je konstantna od 1980. godine. Više su od trećine svih emisija dušikovih oksida antropogene i prvenstveno su posljedica poljoprivrede. ${ }^{43}$ I drugi znanstvenici ističu da je od početka industrijske revolucije do danas „koncentracija ugljikova dioksida u atmosferi porasla za $32 \%$, metana za $10 \%$, a dušikova dioksida za $15 \% " 4$ te se danas smatra da će se do 2100 . godine koncentracija $\mathrm{CO}_{2} \mathrm{u}$ atmosferi povećati za 50\% do 300\%, a kolik će biti stvarni porast, ovisit će, naravno, o stopi gospodarskog rasta, o ponudi i potražnji energije iz fosilnih goriva i uspješnosti poduzetih mjera.

lako skeptici naglašavaju da je doprinos antropogenih aktivnosti ukupnoj emisiji stakleničkih plinova malen i iznosi samo $0,1 \%$, sve više znanstvenika upozorava da je „upravo ta količina presudna”. ${ }^{44}$ lako je navedenih $0,1 \%$ višestruko manje od doprinosa vulkana i raspada biomase $(1,45 \%)$, biološke aktivnosti oceana $(1,45 \%)$ te doprinosa vodene pare (97\%), upravo „trajni porast uzrokovan antropogenom aktivnošću dovodi do poremećaja u uspostavljenoj ravnoteži". ${ }^{44}$ Klimatske promjene zapravo su pokušaj uspostavljanja nove ravnoteže. Sličan proces odvija se u stakleniku, što je dovelo do naziva efekt staklenika. ${ }^{3}$

\section{Antropogeni i prirodni faktori za nastanak globalnog zatopljenja}

Globalno zatopljenje direktno je povezano s efektom staklenika koji je posljedica povećane količine stakleničkih plinova u atmosferi. Efekt staklenika nastaje zbog svojstva atmosfere da propušta velik postotak vidljive Sunčeve svjetlosti koja zagrijava Zemlju, od čega se dio reemitira u obliku dugovalnoga toplinskog zračenja natrag $u$ atmosferu, a najveći dio te energije apsorbira se u atmosferi molekulama vodene pare, ugljikova dioksida te u manjoj mjeri nekih drugih plinova (klorofluorougljici, metan i drugi) i reflektira natrag prema Zemlji. Plinovi čija je koncentracija porasla zagađenjem atmosfere odbijaju dio topline natrag na Zemlju, što izaziva podizanje temperature atmosfere ne bi li se uspostavila nova ravnoteža. Riječ je o plinovima koji se nazivaju zajedničkim nazivom staklenički, a to su vodena para $\left(\mathrm{H}_{2} \mathrm{O}\right)$, ugljikov dioksid $\left(\mathrm{CO}_{2}\right)$, metan $\left(\mathrm{CH}_{4}\right)$, dušikov oksid $\left(\mathrm{N}_{2} \mathrm{O}\right)$, klorofluorougljici (freoni - CFC, freon $11-\mathrm{CCl}_{3} \mathrm{~F}$, freon $\left.12-\mathrm{CCl}_{2} \mathrm{~F}_{2}\right)$, ozon $\left(\mathrm{O}_{3}\right)$ u troposferi, sumporov dioksid $\left(\mathrm{SO}_{2}\right)$, drugi oksidi dušika, ugljikov monoksid (CO) itd. Svi staklenički plinovi u atmosferi se pojavljuju u vrlo malim udjelima. Otprilike $60 \%$ do $70 \%$ efekta staklenika odnosi se na vodenu paru, $25 \%$ na $\mathrm{CO}_{2}, 5 \%$ na $\mathrm{CH}_{4}, 2 \%$ na $\mathrm{N}_{2} \mathrm{O}$ i $1 \%$ na freon, a ostali plinovi imaju pojedinačno manje od $1 \%$ ukupnog efekta staklenika. ${ }^{45}$

Za većinu znanstvenika danas je vrlo vjerojatno da je praćenje porasta stakleničkih plinova praćeno porastom srednje globalne temperature Zemlje koja raste od 
početka 20 . stoljeća za oko $0,3^{\circ} \mathrm{C}$ do $0,6^{\circ} \mathrm{C}$ kontinuirano u posljednjih 80 do 100 godina. $U$ desetogodišnjem razdoblju od 2001. do 2010. godine globalna temperatura je bila za $0,46{ }^{\circ} \mathrm{C}$ viša od prosjeka za razdoblje od 1961 . do 1990 . godine. ${ }^{4}$ Autori iznose podatak i da je između 1906. i 2006. godine, prosječna temperatura porasla za $0,6^{\circ} \mathrm{C}$ do $0,9^{\circ} \mathrm{C}$, a brzina porasta temperature gotovo se udvostručila u posljednjih 50 godina.

Prema DHMZ-u, koji se poziva na proučavanja Svjetske meteorološke organizacije tijekom zadnje četiri dekade, to jest od 1971. do 2010. godine, pokazuje se znakovit porast globalne temperature zraka, koji u prosjeku iznosi $0,17{ }^{\circ} \mathrm{C}$ po dekadi. Nasuprot tome, u odnosu na čitavo promatrano razdoblje između 1880 . i 2010. godine prosječni porast iznosio je samo $0,062{ }^{\circ} \mathrm{C}$ po dekadi. Upravo pri usporedbi s tim podatkom, uočeni porast od $0,21{ }^{\circ} \mathrm{C}$ koji se odnosi na srednje dekadne temperature između razdoblja od 1991. do 2000. godine, kao i uočen daljnji porast tijekom perioda između 2001. i 2010. godine pokazuje se kao znatno veći od porasta srednje dekadne temperature između razdoblja od 1981. do 1990. godine i između 1991 . i 2000 . godine $\left(+0,14^{\circ} \mathrm{C}\right)$, što ujedno predstavlja najveći porast u odnosu na sve sukcesivne dekade od početka instrumentalnih mjerenja. ${ }^{4}$

Dio znanstvenika upozorava na neke probleme povezane s određivanjem točnih vrijednosti srednjih dnevnih, mjesečnih i godišnjih temperatura zraka. Ti problemi, prema njima, znatno dovode u pitanje mogućnosti pouzdanog zaključivanja o trendovima porasta temperatura zraka na planetu, međutim oni koji zastupaju takve ideje su u manjini. ${ }^{42}$

Neke su od mogućih posljedica globalnog zatopljenja i povećanje broja ekstremnih vremenskih događaja (više oluja, valova vrućina, poplava i slično) kojem svijet svjedoči krajem druge dekade 21. stoljeća širom svijeta.

Muller još prije 15 godina navodi da su neke od već prisutnih posljedica globalnog zatopljenja bile vidljive pri promjenama u vodnom sustavu na Zemlji, zatim u obliku pojačanih ekstremnih događaja te kroz zatopljenje oceana koje znatno utječe i na proizvodnju planktona koji apsorbiraju $\mathrm{CO}_{2}$ iz gornjih razina mora i prenose ga zajedno s hranjivim tvarima u dubine. ${ }^{47}$

Zbog otapanja leda, razina mora polako raste. U 20. stoljeću razina mora povisila se za 17 centimetara. Površina ledenjaka (glečera) diljem svijeta smanjuje se, baš kao i površina arktičkoga ledenog pokrova za 2,7\% godišnje, od 1978. godine. Drugi autori govore o podizanju razine mora koja je u posljednjih stotinu godina rasla za 1 do $2 \mathrm{~mm}$ godišnje. Becken donosi podatak da je glo- balna prosječna razina mora od 1961. godine narasla za $1,8 \mathrm{~mm}$ godišnje, a od 1993. godine razina se povećava za $3,1 \mathrm{~mm}$ godišnje, ${ }^{48}$ uz bojazan da bi do 2100 . godine mogla porasti za 15 do $90 \mathrm{~cm}$.

Led na Grenlandu u posljednja se dva desetljeća počeo ubrzano otapati nakon što je bio relativno stabilan do početka industrijske revolucije sredinom 19. stoljeća. Znanstvenici su utvrdili da se grenlandska ledena ploča topi $50 \%$ brže nego u predindustrijsko doba i $33 \%$ brže nego tijekom 20. stoljeća. Tijekom pet godina u razdoblju između 2001. i 2011. godine arktički ledeni pokrov bio je znatno ispod razine višegodišnjeg prosjeka iz razdoblja između 1979. i 2000. godine. ${ }^{46}$ Znanstvenici i najbolji mladi doktorandi iz cijelog svijeta okupljeni oko Schoofa i suradnika pri Sveučilištu UBC u Kanadi prikupljaju tisuće parametara mjerenjima na ledenjacima, pokušavaju razumjeti uzroke ubrzanog otapanja ledenjaka na Arktiku te objasniti razloge klizanja ledenjaka po podlozi simulirajući izgled i karakteristike površine na spoju leda i čvrste stijene, čime bi se možda moglo i predvidjeti buduće otapanje velikih površina ledenjaka. ${ }^{49}, 50$ Riječ je o jednom od najvažnijih istraživanja koje se trenutačno provodi u svijetu, s mogućim dalekosežnim posljedicama po razumijevanje načina otapanja ledenjaka.

\section{Trendovi klimatskih promjena i rizici za prirodne i društvene sustave u budućnosti}

Sva predviđanja za budućnost povezana s postupcima modeliranja klime i klimatskih promjena treba uzimati kritički i s rezervom, s obzirom na to da je osnovno obilježje modeliranja tzv. neizvjesnost (engl. uncertainties).

Znanstvenici dijele izvore neizvjesnosti u tri grupe: na unutarnju (prirodnu) varijabilnost klimatskog sustava koja se veže uz prirodne varijacije unutar klimatskog sustava, zatim na nesavršenost klimatskih modela koja se veže uz činjenicu da su znanstvene spoznaje i razumijevanje klimatskog sustava zasad ograničene jer postoji mnogo procesa u atmosferi, oceanima i ostalim komponentama klimatskog sustava koji još nisu dobro objašnjeni ili su zasad nedovoljno poznati te na treću grupu vezanu uz nepoznavanje buduće koncentracije stakleničkih plinova, što je možda i najveća nepoznanica u klimatskom modeliranju s obzirom na to da doista nitko ne može sa sigurnošću predvidjeti veličinu buduće populacije na Zemlji, način života te budući stupanj industrijskog i tehnološkog razvitka. ${ }^{2}$ Međutim, čak i u slučaju nulte stope daljnjeg ispuštanja $\mathrm{CO}_{2}$ i ostalih stakleničkih plinova u atmosferu, i dalje bi dolazilo do 
zagrijavanja zbog životnog vijeka stakleničkih plinova. Naime, Zemlja je u ovom trenutku toplija za najmanje $0,7^{\circ} \mathrm{C}$ u odnosu prema 1900 . godini te bi se čak i uz nultu stopu daljnjeg rasta koncentracije stakleničkih plinova Zemlja u idućem desetljeću zagrijala za daljnjih $0,5^{\circ} \mathrm{C}$ do $1{ }^{\circ} \mathrm{C} .{ }^{4,51} \mathrm{Na}$ temelju dosadašnjih trendova može se predvidjeti da će porast temperature do 2100 . godine na planeti iznositi između $1,4{ }^{\circ} \mathrm{C}$ i $5,8^{\circ} \mathrm{C}$, a u Europi u rasponu od $2,0^{\circ} \mathrm{C}$ do $6,3{ }^{\circ} \mathrm{C}$, pri čemu bi se temperatura povećavala od sjevera prema jugu Europe. Nadalje, predviđa se da će srednja i sjeverna Europa primati više kiše, a u južnoj Europi prevladavat će više suha klima. Sušne i jake olujne oborine i poplave mogle bi postati učestalije, a smanjit će se broj jako hladnih dana. ${ }^{44}$

Posebno izvješće o globalnom zatopljenju od $1,5^{\circ} \mathrm{C}^{11}$ naglašava da će zatopljenje od antropogenih emisija iz predindustrijskog razdoblja do danas i dalje postojati stoljećima te će i uzrokovati daljnje dugoročne promjene u klimatskom sustavu, kao što je porast razine mora, uz povezane učinke. Izvješće donosi predviđanja prema kojem je malo vjerojatno da će postojeće emisije izazvati globalno zatopljenje od $1,5^{\circ} \mathrm{C}$, već se optimistički predviđa da antropogene emisije (uključujući stakleničke plinove, aerosole i njihove prekursore) vjerojatno neće uzrokovati daljnje zatopljenje za više od $0,5^{\circ} \mathrm{C}$ tijekom sljedeća dva do tri desetljeća ili na vremenskoj skali od jednog stoljeća. Optimistično je i poticajno predviđanje da bi postizanje i održavanje neto nulte globalne antropogene emisije $\mathrm{CO}_{2}$ i opadanje neto zračenja koje nije $\mathrm{CO}_{2}$ zaustavilo antropogeno globalno zatopljenje na višedesetljetnim vremenskim skalama. ${ }^{11}$

Međutim, usprkos najavama, globalne emisije trenutačno su u porastu uz objektivnu opasnost da bi uz nastavak sadašnjih stopa emisija došlo do ukupnog zatopljenja od $1,5^{\circ} \mathrm{C}$ već u razdoblju između 2030. i 2052. godine. ${ }^{11}$ Zbog toga se kao cilj postavlja zadržavanje globalnog zatopljenja unutar $+1,5^{\circ} \mathrm{C}$ kako bi se smanjile ili izbjegle moguće posljedice. Kako bi se sve to ostvarilo, potrebno je postići da globalne emisije $\mathrm{CO}_{2}$ do 2030 . godine padnu za barem 35\% u odnosu na razinu iz 2010. godine u cilju dostizanja „neto nule” oko 2050. godine. Istodobno bi se sve preostale emisije morale uravnotežiti uklanjanjem $\mathrm{CO}_{2}$ iz atmosfere. EU kao jedna od klimatski najprogresivnijih ekonomija trenutačno cilja na smanjivanje emisija od $30 \%$ do 2030 . godine u usporedbi s 2010 . godinom te od $77 \%$ do $94 \%$ do 2050 . godine. ${ }^{52}$

Rizici povezani s klimom za prirodne i ljudske sustave, uz visoku pouzdanost, veći su uz globalno zatopljenje od $1,5^{\circ} \mathrm{C}$ nego trenutačno, ali niži nego uz globalno zatopljenje od $2{ }^{\circ} \mathrm{C}$. Ti rizici ovise o veličini i stopi zagrija- vanja, zemljopisnom položaju, razini razvoja i ranjivosti te izboru i provedbi mogućnosti prilagodbe i ublažavanja. Budući rizici povezani s klimom ovise o stopi i trajanju zatopljenja. Oni su veći ako globalno zatopljenje prelazi $+1,5^{\circ} \mathrm{C}$ nego ako se globalno zatopljenje postupno stabilizira na $+1,5^{\circ} \mathrm{C}$, posebno ako je vršna temperatura visoka (npr. oko $+2{ }^{\circ} \mathrm{C}$ ). Neki utjecaji, uz veliku pouzdanost, mogu biti dugotrajni ili nepovratni, kao što je gubitak nekih ekosustava. ${ }^{52}$

Porast razine mora nastavit će se i nakon 2100. godine, čak i ako je globalno zatopljenje ograničeno na $+1,5{ }^{\circ} \mathrm{C}$ u 21. stoljeću. Ledene plohe na temeljima ispod morske razine mogu imati ključnu ulogu u klimatskom sustavu Zemlje. To nisu samo velika tijela smrznute slatke vode čije bi oslobađanje utjecalo na cirkulaciju oceana i razinu mora, već osjetljivo reagiraju na promjene u okolnim oceanima. Zatopljenje u moru Amundsen i kolaps ledenih polica na Antarktičkom poluotoku doveli su do „znatnih promjena u protoku uzemljenog leda u Zapadnom Antarktiku", gdje je velik dio ledene plohe ispod razine mora. ${ }^{49,50}$

Nestabilnost ledenih ploča na Antarktiku i/ili nepovratni gubitak ledene ploče Grenlanda može dovesti do višekratnog povećanja razine mora tijekom stotina do tisuća godina. Te nestabilnosti mogu se pokrenuti na oko $1,5^{\circ} \mathrm{C}$ do $2{ }^{\circ} \mathrm{C}$ globalnog zatopljenja. Međutim, i uz porast temperature manji od $1,5^{\circ} \mathrm{C}$, globalno podizanje razine mora do 2100 . godine moglo bi biti za $26 \mathrm{~cm}$ do $77 \mathrm{~cm}$ više nego u polaznom razdoblju između 1986. i 2005. godine. ${ }^{52}$

Vjerojatnost pojavljivanja Arktičkog oceana bez leda tijekom ljeta znatno je niža pri globalnom zagrijavanju od $1,5^{\circ} \mathrm{C}$ u usporedbi s globalnim zatopljenjem od $2{ }^{\circ} \mathrm{C}$. $\mathrm{Uz} 1,5^{\circ} \mathrm{C}$ globalnog zatopljenja projicira se jedno arktičko ljeto bez leda na stoljeće, međutim ta je vjerojatnost povećana na barem jedno arktičko ljeto bez leda po desetljeću uz globalno zatopljenje od $2^{\circ} \mathrm{C}$. Srećom, učinci prekoračenja temperature reverzibilni su za arktički ledeni pokrov na dekadnim vremenskim skalama.

Širok raspon literature raspravlja o odnosima između klimatskih promjena i biološke raznolikosti, kako općenito, ${ }^{53}$ tako i specifično u odnosu na turizam. ${ }^{54}$

Na kopnu se predviđa da bi utjecaj na biološku raznolikost i ekosustave, uključujući gubitak vrsta i izumiranje, bio manji na $1,5^{\circ} \mathrm{C}$ globalnog zatopljenja u usporedbi s $2{ }^{\circ} \mathrm{C}$ globalnog zatopljenja.

Od 105000 proučavanih vrsta, za $6 \%$ insekata, $8 \%$ biljaka i $4 \%$ kralježnjaka predviđa se da će izgubiti više 
od polovice svojeg klimatski određenoga zemljopisnog raspona uz globalno zatopljenje od $1,5^{\circ} \mathrm{C}$, u usporedbi s $18 \%$ insekata, $16 \%$ biljaka i $8 \%$ kralježnjaka uz globalno zatopljenje od $2{ }^{\circ} \mathrm{C}$. Utjecaji povezani s drugim rizicima vezanim za biološku raznolikost kao što su šumski požari i širenje invazivnih vrsta niži su uz globalno zatopljenje od $1,5^{\circ} \mathrm{C}$ u usporedbi s $2{ }^{\circ} \mathrm{C}$ globalnog zatopljenja. ${ }^{52}$ Kako se Zemlja sve više približava scenariju maksimalnog porasta temperature, izumiranje prijeti i za gotovo više od $50 \%$ vrsta. ${ }^{55}$

Predviđa se da će oko 4\% (interkvartilni raspon 2 - 7\%) globalne kopnene površine proći transformaciju ekosustava iz jednog tipa u drugi uz globalno zatopljenje od $1,5^{\circ} \mathrm{C}$, u usporedbi s $13 \%$ (interkvartilni raspon $8-20 \%$ ) uz globalno zatopljenje od $2{ }^{\circ} \mathrm{C}$, pri čemu je procijenjeno područje pod rizikom približno $50 \%$ niže uz globalno zatopljenje od $1,5^{\circ} \mathrm{C}$ u usporedbi s područjem pod rizikom uz globalno zatopljenje od $2^{\circ} \mathrm{C}$.

Tundra i borealne šume na visokim zemljopisnim širinama posebno su osjetljive na degradaciju i gubitak uzrokovane klimatskim promjenama, a njihovo će se ugrožavanje nastaviti daljnjim zatopljenjem. Ograničavanjem globalnog zatopljenja na $+1,5^{\circ} \mathrm{C}$, a ne na $+2{ }^{\circ} \mathrm{C}$ spriječilo bi se odmrzavanje permafrosta tijekom stoljeća u rasponu od 1,5 do 2,5 milijuna $\mathrm{km}^{2}$.

Predviđanja pokazuju da se čak i uz porast temperature od $1,5{ }^{\circ} \mathrm{C}$ očekuje smanjenje koraljnih grebena za $70 \%$ do $90 \%$, što je ipak znatno optimističnije od scenarija globalnog zatopljenja od $2{ }^{\circ} \mathrm{C}$ pri kojem bi nestalo više od $99 \%$ koraljnih grebena. Jedan globalni model ribarstva, na primjer, predviđa smanjenje globalnoga godišnjeg ulova za morski ribolov od oko 1,5 milijuna tona uz povećanje temperature za $1,5^{\circ} \mathrm{C}$ u usporedbi s gubitkom od više od tri milijuna tona uz globalno zatopljenje od $2^{\circ} \mathrm{C} .52$

Projekcije studija pokazuju da će rizici od suša i deficita padalina biti veći uz $+2{ }^{\circ} \mathrm{C}$ u usporedbi $s+1,5^{\circ} \mathrm{C}$ globalnog zatopljenja u nekim regijama. Također, predviđa se da će rizici od velikih oborinskih događaja biti veći uz globalno zatopljenje od $2{ }^{\circ} \mathrm{C}$ u odnosu na $1,5^{\circ} \mathrm{C}$ globalnog zatopljenja u nekoliko područja sjeverne hemisfere i/ili visokih nadmorskih visina, istočnoj Aziji i istočnoj Sjevernoj Americi.

Studije provedene za Europu pokazale su da bi uz $2{ }^{\circ} \mathrm{C}$ globalnog zatopljenja došlo do snažnog povećanja srednje vrijednosti oborina u središnjoj i sjevernoj Europi zimi, ali samo na području sjeverne Europe ljeti i sa smanjenjem srednje količine padalina u srednjoj i južnoj Europi ljeti. ${ }^{56,57}$
Predviđa se sa srednjom pouzdanošću da će obilne padaline biti povezane s tropskim ciklonima više uz globalno zatopljenje od $2{ }^{\circ} \mathrm{C}$ u usporedbi s globalnim zatopljenjem od $1,5^{\circ} \mathrm{C}$. Kao posljedica obilnih oborina, predviđa se da će udio globalnoga kopnenog područja pogođenog opasnostima od poplava biti veći uz globalno zatopljenje od $2{ }^{\circ} \mathrm{C}$ u odnosu na globalno zatopljenje od $1,5^{\circ} \mathrm{C} .{ }^{52}$

Populacije s nerazmjerno većim rizikom od štetnih posljedica s globalnim zatopljenjem od $1,5^{\circ} \mathrm{C}$ i više uključuju neke autohtone narode i lokalne zajednice ovisne o poljoprivrednom ili obalnom životu. Regije s nerazmjerno većim rizikom uključuju arktičke ekosustave, suhe regije te male otočne države u razvoju. Predviđa se da će i stoka biti izložena negativnom utjecaju s porastom temperature, uz promjene u kvaliteti hrane, širenju bolesti i dostupnosti vodnih resursa. Ograničavanje zatopljenja na $+1,5^{\circ} \mathrm{C}$ predviđa smanjenje gubitka prinosa kukuruza, riže, pšenice i potencijalno drugih usjeva žitarica, osobito u podsaharskoj Africi, jugoistočnoj Aziji i Srednjoj i Južnoj Americi, i u nutritivnoj kvaliteti riže i pšenice ovisne o $\mathrm{CO}_{2}$. Smanjenje predviđene dostupnosti hrane veće je uz $2^{\circ} \mathrm{C}$ nego uz $1,5^{\circ} \mathrm{C}$ globalnog zatopljenja u Sahelu, južnoj Africi, Sredozemlju, srednjoj Europi i Amazoniji. ${ }^{52}$

Predviđa se da će rizici za globalni agregirani gospodarski rast zbog utjecaja klimatskih promjena biti niži uz $+1,5{ }^{\circ} \mathrm{C}$ nego uz $+2{ }^{\circ} \mathrm{C}$ do kraja ovog stoljeća, isključujući troškove ublažavanja, ulaganja u prilagodbu i koristi od prilagodbe. Predviđa se da će zemlje u tropskim i južnim hemisferama doživjeti snažan utjecaj na gospodarski rast zbog klimatskih promjena, posebice ako bi globalno zatopljenje poraslo $\mathrm{s}+1,5^{\circ} \mathrm{C}$ na $+2^{\circ} \mathrm{C}$. Izloženost višestrukim i složenim rizicima povezanima s klimom povećava se uz $1,5^{\circ} \mathrm{C}$ do $2{ }^{\circ} \mathrm{C}$ globalnog zatopljenja, s većim udjelom ljudi koji su tako izloženi i podložni siromaštvu u Africi i Aziji. Za globalno zatopljenje od $1,5^{\circ} \mathrm{C}$ do $2^{\circ} \mathrm{C}$ rizici u područjima vezanima uz energiju, hranu i vodu mogli bi se preklapati prostorno i vremenski, stvarajući nove i pogoršavajući trenutačne opasnosti, izloženosti i ranjivosti koje bi mogle utjecati na sve veći broj ljudi i regija. ${ }^{52}$ Ovisno o budućim socioekonomskim uvjetima, ograničavanje globalnog zatopljenja na $+1,5{ }^{\circ} \mathrm{C}$ može smanjiti udio svjetske populacije izložene klimatskim promjenama uzrokovanim povećanjem nestašice vode do $50 \%$, iako postoji znatna varijabilnost između regija. ${ }^{52}$

Znanstvenici predviđaju mogući izlaz iz postojeće situacije naglašavajući da do 2100 . godine treba postići razinu balansiranu „neto nulu” glede emisija, što bi zahtijevalo ukupno uklanjanje između 100 i $1000 \mathrm{Gt} \mathrm{CO}_{2}$ iz atmosfere, pri čemu metode za uklanjanje ugljika variraju od onih prirodnih poput sadnje drveća te primjene 
poljoprivrednih praksi koje zadržavaju veću količinu $\mathrm{CO}_{2}$ u tlu, sve do tehnoloških rješenja kojima se emisije $\mathrm{CO}_{2}$ hvataju i pohranjuju pod zemljom. ${ }^{52}$

Tijekom 50-godišnjeg razdoblja (1961. - 2010.) došlo je do zatopljenja u cijeloj Hrvatskoj, što je dokazano praćenjem trendova srednje, srednje minimalne i srednje maksimalne temperature zraka koje pokazuju da su promjene veće $u$ kontinentalnom dijelu zemlje nego na obali i u dalmatinskoj unutrašnjosti. Posebno zabrinjava podatak da su najveće promjene zabilježene kod parametra praćenja maksimalne temperature zraka, i to od $+0,3^{\circ} \mathrm{C}$ do $+0,4{ }^{\circ} \mathrm{C}$ na 10 godina. Uočeno zatopljenje očituje se i u svim indeksima temperaturnih ekstrema, pozitivnim trendovima toplih temperaturnih indeksa (topli dani i noći te trajanje toplih razdoblja) te s negativnim trendovima hladnih temperaturnih indeksa (hladni dani i hladne noći te duljina hladnih razdoblja. ${ }^{46}$ DHMZ predviđa velike promjene do 2040. godine, pri čemu se, na primjer, očekuje da će temperatura zimi porasti između $1,1^{\circ} \mathrm{C}$ i $1,2^{\circ} \mathrm{C}$. Očekuje se i porast vlažnosti zraka, dok se srednja brzina vjetra neće mijenjati, a sve će biti popraćeno manjim porastom oborina. U proljeće se predviđa da će na otocima Dalmacije temperatura biti viša za $0,7^{\circ} \mathrm{C}$ te u sjeverozapadnoj Hrvatskoj viša za više od $1^{\circ} \mathrm{C}$. Također se očekuje smanjenje Sunčeva zračenja najviše na Jadranu i gorskoj Hrvatskoj uz porast vlažnosti zraka i manji porast količina oborine. Tijekom ljeta predviđanja su da će temperatura porasti između $1,1{ }^{\circ} \mathrm{C}$ i $1,2^{\circ} \mathrm{C}$, uz očekivani porast količine Sunčeva zračenja. Također se predviđa porast vlažnosti zraka, koja bi bila najveća u odnosu prema ostalim godišnjim dobima, posebice na Jadranu, te također porast srednje brzine vjetra, posebice na Jadranu, uz smanjenje količina oborina. Jeseni bi obilježio porast temperature između $0,9{ }^{\circ} \mathrm{C}$ u istočnoj Slavoniji te za oko $1,2^{\circ} \mathrm{C}$ na Jadranu, a u zapadnoj Istri i do $1,4{ }^{\circ} \mathrm{C}$. Očekuje se također porast količine Sunčeva zračenja, porast vlažnosti zraka te porast srednje brzine vjetra, što bi bilo posebno izraženo na sjevernom Jadranu i što bi predstavljalo promjenu od oko 20 do $25 \%$ u odnosu prema referentnom razdoblju uz smanjenje količina oborina. ${ }^{46}$ Iskazane projekcije, ma koliko mogle biti samo orijentacijske i nesigurne, upućuju na važnost ozbiljnog promišljanja budućnosti hrvatskog gospodarstva kojem je turizam najvažnija grana, ali i s turizmom povezanih drugih gospodarskih aktivnosti poput poljoprivrede, vodoopskrbe, energetike i uslužne djelatnosti. ${ }^{4}$ Opisana predviđanja prema modelima, uz potpunu svijest o neizvjesnosti predviđanja, svakako je potrebno uzeti u obzir kada se planira razvoj hrvatskog turizma u budućnosti.

\section{Turizam i klimatske promjene}

Turizam je jedna od najvećih i najbrže rastućih globalnih industrija, s visokim stopama rasta te ima važnu ulogu u nacionalnim i lokalnim gospodarstvima, ${ }^{58}$ kako u Hrvatskoj (Ružić i Demonja 2013) tako i diljem svijeta. ${ }^{9}$

Turizam kao svjetska pojava ima tendenciju stalnog rasta, čemu pridonose porast standarda, kupovne moći, višak slobodnog vremena, promjena kulturnih i civilizacijskih normi, ali i povećanje stresa, promjena životnih stilova, zdravstveni razlozi itd. ${ }^{59}$

Još 2007. godine turizam je sudjelovao s oko 3,6\% u svjetskom bruto domaćem proizvodu (BDP) i zapošljavao 231 milijuna ljudi, što je činilo 8,3\% ukupno zaposlenih. ${ }^{79}$ Deset godina kasnije, 2016. godine, prema procjenama UNWTO-a, u svijetu je ostvareno 1,235 milijardi međunarodnih dolazaka te ostvaren prihod od 1,4 milijarde američkih dolara i udio u svjetskom BDP-u od $10 \%$, što je trostruko povećanje udjela u BDP-u u odnosu na period prije deset godina. Najviše dolazaka bilježi Europa s udjelom od 51\%, zatim Azija i Pacifik s udjelom od $24 \%$ te Amerika s udjelom od $16 \% .{ }^{60}$ Podaci govore o najvećem rastu međunarodnih turističkih dolazaka u sedam godina od 2010. godine te upućuju na oporavak odredišta koja su posljednjih godina bila izložena sigurnosnim izazovima. ${ }^{60}$ Ekonomski rast rezultirao je snažnom izlaznom potražnjom na glavnim izvornim tržištima, a zabilježen je snažan oporavak potražnje na tržištima u nastajanju u Brazilu i Ruskoj Federaciji nakon nekoliko godina pada.

Turisti daju vrlo visoke ocjene destinacijama s povoljnim klimatskim uvjetima te su oni važan čimbenik prilikom donošenja odluka o odabiru destinacije. Istodobno, klima je ,jedan od važnih činitelja razvoja turizma", a slijedom toga djeluje i na učinke koje turizam ostvaruje. ${ }^{61}$ Također, s obzirom na to da je klima jedan od važnijih pokretača turizma, u budućnosti će imati još važniju ulogu u definiranju privlačnosti pojedine destinacije, kao i odlučivanju turista oko izbora destinacije. ${ }^{48}$ Osim toga, klimatske promjene promijenit će uvjete $u$ kojima će djelovati turističke destinacije te znatno utjecati na upravljanje turističkim tokovima i imovinom te na uspješno poslovanje turističkih poduzeća. ${ }^{4}$

Klimatske promjene imale su znatan utjecaj na putovanja i turizam kroz povijest. ${ }^{62}$ Međutim, u novije doba, više nego ranije, klimatske su promjene globalnog ka- 
raktera i ozbiljno determiniraju razvoj i budućnost turizma u širem obuhvatu turističkih regija i svijeta u cjelini. Klimatske promjene ne predstavljaju samo jedinstveni izazov za čovječanstvo, već utječu na sve aspekte ljudskog života, uključujući turizam, ali i postaju globalni ekološki problem. ${ }^{63}$

Koliko god postoji suglasje u akademskim krugovima o povezanosti klimatskih promjena i turizma, posebice održivog razvoja turizma, ima relativno malo znanstvenih radova objavljenih unazad 20 godina koji bi se bavili proučavanjem međuutjecaja klimatskih promjena i turizma. Farid i suradnici istražili su sve radove zastupljene $u$ indeksiranim bazama WoS i Scopus za period između 1996. i 2016. godine i pronašli su samo 95 radova koji se bave pitanjem povezanosti klimatskih promjena i održivog razvoja, od kojih je 80 bilo objavljeno u 43 indeksirana časopisa. ${ }^{64}$ lako je najveći broj, više od $92 \%$, bio objavljen na engleskom jeziku, vidljivost tih radova praćena kroz citiranost zapravo je vrlo mala, jer 37,9\% radova nije nikad bilo citirano, a samo $14,7 \%$ odnosno 14 radova imalo je više od 50 citata, što govori o vrlo ograničenom akademskom interesu za navedenu temu. Više od sto citata imala su samo tri rada, ${ }^{65-69}$ što je još jedna potvrda slabog odjeka radova koji se bave klimatskim promjenama i održivim razvojem u akademskoj zajednici.

Brojni autori pokazali su da postoji jaka povezanost između turističkih kretanja i klimatskih prilika. ${ }^{48}$ Analizom izdvojenih radova može se zaključiti da utjecaj klimatskih promjena neće biti jednako raspoređen po cijelom svijetu, već će biti najviše pogođeni oni dijelovi koji nisu nužno i najviše pridonijeli promjenama klime male otočne države, priobalna područja, visoka planinska područja i zemlje u razvoju kojima je turizam glavna ekonomska aktivnost. Posebno su osjetljive pojedine turističke destinacije, budući da klima utječe i na odabir turističke destinacije i turističku potrošnju te znatno utječe posebice u segmentu trajanja, ali i ukupne kvalitete turističke sezone.

Klima je prepoznata kao ključni pokretač turizma i važan atribut destinacije. ${ }^{20}$ Klima je vrednovana ili kao glavni turistički resurs, na primjer u slučaju destinacija za plažu, ${ }^{71}$ ili djeluje kao posrednik koji omogućuje turističke aktivnosti i uživanje. ${ }^{72}$ Pojednostavljeno, klimatske promjene mogu imati pozitivan ili negativan utjecaj na turizam, ali i turizam indirektno pridonosi postojećim klimatskim promjenama. ${ }^{73}$ Neki autori naglašavaju i važnost klime u mjestima boravka samih turista, koja također može poticati na promjenu mjesta boravka i izbor destinacije u kojoj je klima za turista povoljnija nego kod kuće (push faktor). Nepovoljna klima ili loši vremenski uvjeti, bilo u godini putovanja bilo prethodne godine,$^{74}$ djeluju kao poticajni faktor za turiste da putuju u toplija i suša mjesta. ${ }^{75}$

Navedeno potvrđuje da se može jasno naglasiti da je međuodnos turizma i klime višestruk i složen, ${ }^{76}$ posebice s obzirom na to da klima predstavlja ključni iskoristivi resurs, ali i ograničavajući faktor kad se govori o njezinoj ulozi u turizmu. ${ }^{77}$ Autori su također naglasili da je odnos između klimatskih promjena i turizma dvosmjeran, ${ }^{78}$ odnosno u literaturi se razrađuje ideja da postoji dvosmjerni međuodnos djelovanja između turizma i klimatskih promjena koji ima vrlo važne ekonomske i razvojne implikacije u brojnim dijelovima svijeta.

O procesu svojevrsne dvosmjerne ulice promjena u oba pravca djelovanja i dvostrukoj povratnoj sprezi odnosno međuovisnosti uzroka i posljedica za turizam i za klimatske promjene govore i Perić i Šverko Grdić, koji ideju detaljnije razrađuju od prethodnika. ${ }^{79,80}$ Također, autori iznose zaključak koji se nameće u odnosu klima - turizam tako da se njihov odnos karakterizira kao uzajaman proces koji će rezultirati nekim od neočekivanih procesa unutar turističkih i klimatskih sustava koji će nadalje utjecati na brojne turističke destinacije u svijetu. ${ }^{71}$

\section{Utjecaj klimatskih promjena na turizam}

Turistička djelatnost vrlo je ovisna o aktivnostima koje se odvijaju na otvorenom, a one ovise o klimi. Zbog toga klima postaje najvažniji činitelj kada se definira destinacija za odmor i direktno je povezana s dokolicom, turističkim doživljajem i zadovoljstvom, ${ }^{79}$ jer je turistima iznimno važan boravak na otvorenom i uživanje u krajoliku ili suncu. ${ }^{81}$

Više recentnih studija pokazuje da klima i klimatske varijacije imaju niz utjecaja na turističke destinacije, turistički promet i turizam kao ekonomsku granu. ${ }^{82,83}$ Klima izravno utječe na širok raspon resursa okoliša koji su kritični za turizam. ${ }^{84}$ Proizlazi da gotovo svaka klimatska promjena ima poseban značaj za dugoročno pozicioniranje turističkih destinacija na svjetskom tržištu. ${ }^{85,86}$

Očekuje se da će turisti iz europskih zemalja koji trenutačno dominiraju međunarodnim putovanjima uzeti više domaćih praznika kako bi iskoristili nove klimatske prilike bliže domu. Hamilton tvrdi da, kako se hladna područja Europe bude zagrijavala, privlačit će više turista, ali kada srednja godišnja temperatura prijeđe $14^{\circ} \mathrm{C}$, posjetit će ih manje turista. Slično tome, dijelovi koji će u početku generirati manje turista kada temperatura 
dosegne $18{ }^{\circ} \mathrm{C}$ generirat će se više turista jer će ljudi tražiti prilike za putovanja do hladnijih klimatskih uvjeta. ${ }^{48}$ Nadalje, Pike naglašava da će „klimatske promjene imati direktan utjecaj na stvaranje imidža destinacije u skoroj budućnosti”. ${ }^{87}$

Važno je istaknuti da sve više turista prilikom izbora destinacije traži podatke o klimi i vremenu u mjestu i regiji u koju putuju. Neka provedena istraživanja pokazala su da „čak $73 \%$ ispitanih njemačkih turista, a $42 \%$ prije rezervacije smještaja, potražuju informacije o klimi u svojim destinacijama za odmor".88

Znanstvenici su suglasni da međunarodna turistička kretanja u Europi ovise o brojnim klimatskim elementima, među kojima se posebno izdvajaju temperatura te broj sunčanih dana i sati u odnosu na broj kišnih dana..$^{89}$ De Freitas je razvrstao različite aspekte turističke klime u estetsku, fizičku i toplinsku. Termalna komponenta opisuje kako se turist osjeća ugodno. Fizička dimenzija odnosi se na netemperaturne klimatske uvjete kao što su vjetar i kiša i važno je ocijeniti je li određena aktivnost moguća ili ne. Estetski aspekt opisuje psihološku perspektivu jer turist uživa u određenim klimatskim uvjetima, primjerice svjetlu ili stvaranju oblaka. ${ }^{77}$

Prilikom samog dolaska na destinaciju turist može, prema De Freitasu, svoje ponašanje ovisno o klimatskim prilikama usmjeravati tako da izbjegava područja nepovoljnih vremenskih ili klimatskih uvjeta, promijeni aktivnost u skladu s vremenskim uvjetima, koristi se strukturnim ili mehaničkim pomagalima, podesi toplinsku izolaciju tijela ili usvoji pasivno prihvaćanje. ${ }^{77}$

Naime, važno je naglasiti da su turizam i rekreacijsko sudjelovanje po definiciji rezultat izbora turista i, iako izbori nisu ograničeni, uključena je velika fleksibilnost. Turisti imaju znatan izbor o tome hoće li ili ne odabrati putovanje, kamo ići, koje aktivnosti izabrati i kada putovati. Naime, budući da je proizvod turizma iskustvo, sudionici mogu zamijeniti aktivnosti i lokacije bez velikog gubitka u kvaliteti svoje rekreacije. Uz brojne mogućnosti za turizam i rekreaciju koje danas pruža globalizirani svijet, većina potencijalnih sudionika vjerojatno će moći zadovoljiti svoje potrebe za slobodnim vremenom i na drugim destinacijama. Važno je razumjeti kako alternativne mogućnosti procjenjuju potencijalni sudionici, budući da izbori nisu ograničeni i, ako su budući izbori ograničeni modificiranom klimom, sudionici mogu zamijeniti jednu aktivnost drugom ili jednu lokaciju drugom..$^{90}$

S obzirom na navedeno može se zaključiti da je motivacija turista za doživljavanje određene klime vrlo važna prilikom donošenja odluka o izboru mjesta i vremena putovanja, što je potvrđeno u istraživanjima turističke potražnje, primjerice u Njemačkoj ${ }^{91}$ odnosno Velikoj Britaniji i Kanadi. ${ }^{92}$ Lohmann i Kaim ističu da turistički tijekovi ovise s jedne strane o sposobnosti za putovanje i motivacije za putovanje na strani potražnje te atraktivnosti, pogodnosti i pristupačnosti na strani destinacije i naglašavaju da su, što se tiče atraktivnosti odredišta, vremenski faktor i klima od posebne važnosti. ${ }^{91}$

Izravni učinci klimatskih promjena na turizam opisani su u nizu studija koje pokazuju da će klimatske promjene utjecati na izbor odredišta turista zato što neka odredišta zbog navedenih promjena više neće u potpunosti zadovoljavati potrebe turista. Naime, sve turističke destinacije osjetljive su na vremenske prilike koje klima određenog područja nosi sa sobom, a one uključuju razlike u temperaturama zraka koje variraju od ekstremno vrućih do nepodnošljivo hladnih, kao i sušnih razdoblja, ali i razdoblja oluja i kiša, koje ne utječu samo na udobnost i sigurnost turista, već i na krajobraz destinacije, koji može biti privlačan ili odbojan s obzirom na želje i potražnju turista. Kao posljedica klimatskih promjena neke destinacije postat će manje atraktivne, a neke dobiti na atraktivnosti, što će dovesti do toga da će neki turistički smjerovi znatno promijeniti svoje tokove, pri čemu će rasti interes za neke nove destinacije i aktivnosti, a u isto će se vrijeme postojeće destinacije suočiti $s$ velikim promjenama u kojima će morati prolaziti postupak prilagodbe kako bi održale sadašnju poziciju na tržištu ili se repozicionirale.

Konkretno, prema UNDP-u, opće promjene klime i vremenskih prilika izravno djeluju na privlačnost određene lokacije za turiste i rekreativce. ${ }^{93}$ Opće promjene klime neizravno utječu na specifične značajke okoliša, uključujući vegetaciju, životinjske vrste i krajolik, koji također utječu na turizam i rekreaciju. S klimatskim promjenama povezane su i štete za turističku infrastrukturu zbog ekstremnih vremenskih prilika, kao i promjena percepcije sigurnosti odredišta od strane turista (mogući toplinski udari, požari, pijavice, poplave itd.), uz dodatan utjecaj na pojavu zdravstvenih problema uzrokovanih klimatskim promjenama (smrtnost/bolest zbog toplinskih udara, pojava zaraznih bolesti).

Neizravni učinci klimatskih promjena očituju se kroz promjene u okolišu, a vežu se uz činjenicu da prirodni okoliš i pridruženi ekosustavi predstavljaju „presudan resurs za turizam"93 te će stoga promjene okoliša uzrokovane klimatskim promjenama imati utjecaja na brojna turistička odredišta. ${ }^{94}$ Grupa neizravnih utjecaja klimatskih promjena na turizam veže se uz one promjene 
u okolišu koje su zbog količine padalina i porasta temperature povezane $s$ podizanjem razine mora i razine jezera, promjenama u režimu i tokovima rijeka i potoka te posljedično promjenama u raspoloživoj količini, dostupnosti i kakvoći vode za piće.

Na problem utjecaja klimatskih promjena na količinu padalina jasno upozorava Krželj, koja navodi da je fenomen globalnog zatopljenja povezan s promjenama u oborinama, primijećenima u količini, intenzitetu, učestalosti i tipu oborina, uz znatno smanjenje volumena i rasprostranjenosti količina i površina pokrivenih snijegom i ledom, čije otapanje direktno determinira količinu vode u vodenim tokovima koji se direktno pune iz prinosa povezanih s planinskim područjima. ${ }^{45} \mathrm{Kao}$ direktna posljedica klimatskih promjena u raznim dijelovima svijeta može se uočiti porast udjela velikih količina oborina posebice u kratkim razdobljima, što zbog prirodnih karakteristika okoliša, riječnih korita ili popratne infrastrukture vrlo često dovodi do poplava u nekim dijelovima svijeta, dok je istodobno, kao potvrda anomalija i ekstrema, u drugim dijelovima Zemlje zabilježeno udvostručenje sušnih područja. Ako se ostvare procjene o nastavku porasta globalne temperature u budućnosti, procjenjuje se da će se i dalje povećavati učestalost velikih oborina u kratkim razdobljima, što će dovoditi do daljnjih porasta poplava u jednim dijelovima svijeta te istodobno povećanja broja sušnih područja uz evidentne promjene u riječnim dotocima uzrokovane prije svega promjenama u količini i vrsti oborina. Posebno je izložena južna Europa, a time i dalmatinski dio Hrvatske, gdje se može očekivati znatno smanjenje dotoka rijeka koje se ulijevaju u Jadransko more, sa znatnim promjenama u sezonskim dotocima. Krželj također ističe da se u područjima gdje su u zimskom razdoblju uobičajene snježne padaline mogu uočiti promjene u vidu smanjenja proljetnoga riječnog dotoka, što se objašnjava manjim količinama snježnih padalina zimi, što ukazuje na promjene u vrsti padalina u tim godišnjim dobima. ${ }^{45}$ Posljedično, anomalije riječnih dotoka povezane su s variranjima u količini otopljene soli u morskoj vodi, tj. salinitetu morskog područja, čime se mijenja i niz fizikalnih, kemijskih i bioloških karakteristika morskog ekosustava, koje zajedno s promjenom temperature mogu utjecati kako na promjene u morskim strujanjima tako i na rasprostranjenost morskih organizama, što ima direktne posljedice ne samo za ribarstvo i gospodarstvo krajeva orijentiranih na more nego i za atraktivnost turističkih destinacija, orijentaciju hotelske industrije te u konačnici i na mogućnost daljnje orijentacije turizma samo na prodaju koncepta „sunce i more”. 45
Neizravan utjecaj klimatskih promjena na turizam očituje se kroz utjecaj na promjenu privlačnosti odredišta povezanih s vodenim ekosustavima i staništima koji utječu na ponudu turističkih usluga. Neosporno je da promjene temperatura pitke i morske vode zbog globalnog porasta temperature neizravno utječu na privlačnost odredišta zbog pojačanog cvjetanja mora te porasta stranih vrsta koje uništavaju vodeni ekosustav. Budući da se 90\% turističkih kapaciteta Hrvatske nalazi na moru, utjecaj klimatskih promjena na morski okoliš od iznimnog je značaja.

Konačno, promjene i degradacija rijetkih ekosustava uz smanjenje bioraznolikosti izravno utječu na turizam u nacionalnim parkovima i razvoj ekoturizma (otežano promatranje ptica, nefunkcionalne ekološke staze itd.), a neizravno utječu na turizam povezan s prirodom, s obzirom na to da krajobrazni ekosustavi gube vrijednost. ${ }^{93}$

\section{Utjecaj turizma na klimatske promjene}

Prepoznate su i opisane brojne, kako pozitivne tako i negativne posljedice turizma na okoliš i lokalnu zajednicu, što je posljedica činjenice da je turizam iznimno velik potrošač i korisnik prostora. Aktivnost turističkih objekata i infrastrukture ugrožavaju kvalitetu okoliša onečišćavanjem voda zbog visoke koncentracije turista u kraćem razdoblju, degradacijom prirodnog krajolika, štetom na flori i fauni, povijesnim spomenicima, zakrčenošću i neodgovarajućom infrastrukturom, bacanjem otpada i velikom potrošnjom energije. Na će taj način turizam tijekom ovog stoljeća ozbiljno ugrožavati prirodne turističke činitelje i utjecati na promjene kretanja i ponašanja turista s moguće nepoželjnim ekonomskim učincima na nacionalna gospodarstva. ${ }^{79}$

Posebno je zabrinjavajuće što turizam znatno pridonosi klimatskim promjenama s obzirom na to da transport, smještaj i ostale aktivnosti znatno pridonose povećanoj emisiji stakleničkih plinova koja će se osloboditi, što ovisi o odabiru načina putovanja, udaljenosti između zemlje stanovanja i željene turističke destinacije te danima boravka u izabranoj destinaciji. Emisije od turizma, uključujući s jedne strane transport, a s druge smještaj i aktivnosti, iznose najmanje $5 \%$ globalnih emisija $\mathrm{CO}_{2},{ }^{95}$ dok se danas većina autora slaže o oko $8 \%$ globalnih emisija $\mathrm{CO}_{2}$. Procjene o najmanje „5\% globalnih emisija $\mathrm{CO}_{2}$ povezanih s turizmom" potvrđuju i drugi autori. ${ }^{96}$ Osim znatnog doprinosa ukupnoj količini ispuštenog $\mathrm{CO}_{2}$, turizam pridonosi emisijama i niza drugih plinova, koji također zagađuju zrak, no one nisu u tolikoj mjeri u fokusu interesa istraživača, iako također pridonose klimatskim promjenama. 
$\mathrm{U}$ radovima od prije nekoliko godina autori su iznosili podatak da u „oko $5 \%$ globalnih emisija $\mathrm{CO}_{2}$ koje se vežu uz turizam, promet ima udio od $4 \%, 1 \%$ otpada na smještaj, a mali dio na ostale turističke aktivnosti", ${ }^{60}$ pri čemu se danas govori o $8 \%$ globalnih emisija koje se vežu uz turizam. Udio turizma u emisiji $\mathrm{CO}_{2}$ približno je jednak udjelu kemijske industrije, a kad bi turizam bio država, „bio bi peti na listi najvećih zagađivača”, i to iza SAD-a, Kine, Rusije i Indije, a ispred velikih zagađivača kao što su Japan i Njemačka. ${ }^{71}$ Podatak o udjelu turizma od $5 \%$ u globalnim emisija $\mathrm{CO}_{2}$ treba doista uzeti s rezervom, s obzirom na to da se izvori referiraju na referencije koje se vežu na 2005. godinu, a prema istraživanju UNWTO-a „Tourism 2020 Vision” predviđa se da će 2020. godine biti 1,6 milijardi dolazaka, od čega gotovo 400 milijuna udaljenih destinacija, ${ }^{97}$ što znači povećanje za oko $100 \%$ u odnosu na 2005. godinu, što će neizbježno dovoditi i do dodatnog opterećenja biosfere većim količinama $\mathrm{CO}_{2}$ iz turizma, a što se iskazuje podatkom o $8 \%$ globalnih emisija koje se danas vežu uz turizam.

Navedeno je da najveći udio u globalnim emisija $\mathrm{CO}_{2}$ ima transport, i to čak $94 \%$, pri čemu je najveći zagađivač avionski prekooceanski promet. ${ }^{98}$ Takav podatak uz predviđanja za budućnost dodatno zabrinjava, budući da postoje predviđanja ,porasta udjela prekooceanskih avioputovanja 2020. godine, u odnosu na baznu 1995. godinu, s $18 \%$ na $24 \%$ ". ${ }^{11}$

Udio emisija u Europi povezanih s turističkom djelatnošću nešto je niži od globalnih 5\% i iznosi oko 3,1\% ukupnih antropogenih $\mathrm{CO}_{2}$ emisija prouzrokovanih izgaranjem fosilnih goriva i industrijskim procesima, djelomično i zato što je unutar Europe automobil, a ne avion, najčešće sredstvo koje se upotrebljava za odlazak u neku turističku destinaciju. ${ }^{71}$

U drugim dijelovima svijeta poput SAD-a znatno je veći postotak emisija $\mathrm{CO}_{2}$ vezanih uz transport pa se iznosi podatak da je čak „, $76,5 \%$ turističkih emisija $\mathrm{CO}_{2}$ uzrokovano transportom, dok je $15 \%$ uzrokovano odmorom, $2,7 \%$ emisija dolazi iz restorana, $1 \%$ od prodaje i $4,8 \%$ od ostalih aktivnosti". ${ }^{76}$

Očekuje se da će emisije stakleničkih plinova kako vrijeme odmiče biti još i veće. ${ }^{4}$ Neke procjene za razdoblje do 2035. godine iznose da bi utjecaj turizma na klimatske promjene mogao znatno rasti jer se predviđa da će globalni turizam porasti za 179\%, dok će noćenja porasti za 156\%, a istodobno kilometri koje će proći turisti povećat će se za $222 \%$, dok će se emisije $\mathrm{CO}_{2}$ povećati za $152 \% .{ }^{95}$ Šverko Grdić također prenosi podatak da avioturisti imaju udio od 17\% ukupnog broja turista, ali da uzrokuju oko $40 \%$ emisija $\mathrm{CO}_{2}$ od turizma. ${ }^{71}$ Prenosi i podatak prema kojem iako interkontinentalna putovanja predstavljaju udio od samo 2,2\%, njihov doprinos emisijama $\mathrm{CO}_{2}$ predstavlja $16 \%$ ukupnih turističkih emisija. Sistematizirajući opterećenje po okoliš kroz procjenu prosječne potrošnje energije Šverko Grdić, donosi podatak o:

„potrošnji od oko $170 \mathrm{MJ}$ po međunarodnom putovanju uz emitiranje oko $27 \mathrm{~kg} \mathrm{CO}$, što je više nego dvostruko od emisija koja se vežu uz domaća putovanja u razvijenim ekonomijama koja emitiraju u atmosferu oko $11 \mathrm{~kg} \mathrm{CO}_{2}$, te deseterostruko više nego u ekonomijama u razvoju gdje se emitira oko $2,7 \mathrm{~kg} \mathrm{CO}_{2}$ po putovanju". ${ }^{71}$

Doprinos smještaja u ukupnoj potrošnji energije, a time i posljedičnom zagađenju u stalnom je porastu i danas daleko premašuje podatke koji se odnose na početak 21. stoljeća, prema kojima je 2001. godine na globalnoj razini bilo zabilježeno 5,2 milijardi noćenja u različitim vrstama smještaja $s$ prosječnom potrošnjom energije po krevetu (za smještaj i dodatne aktivnosti) od 97,5 MJ, što je bio „ekvivalent ukupno potrošenih $508 \mathrm{PJ}$, odnosno ispuštenih $81 \mathrm{Mt}$ emisija $\mathrm{CO}_{2} \mathrm{u}$ atmosferu". ${ }^{38}$

Upravo Perić i Šverko Grdić ukazuju na paradoks prema kojem turizam, na više načina, ugrožava kvalitetu okoliša, a istodobno ovisi upravo o održavanju visoke kvalitete okoliša, koji je njegov osnovni preduvjet i resurs budućeg razvoja. ${ }^{79}$ Tragom navedenog autori dalje naglašavaju da se međuodnos klimatskih promjena i turizma i obratno može sagledavati kroz dva konceptualna modela, pri čemu prvi model klimatske promjene promatra u smislu ublažavanja i prilagodbe, a drugi konceptualni model govori da je povezanost između turizma i klimatskog sustava dinamična, ima više razina i povratnih veza koje se mogu analizirati u cilju poduzimanja odgovarajućih mjera. Takav je pristup na tragu Dwyerovih razmatranja da su klimatske promjene globalni izazov koji zahtijeva dugoročne mjere prilagodbe u cilju izbjegavanja okolišnih, socijalnih i ekonomskih posljedica. ${ }^{4}$

\section{Međuutjecaj klimatskih promjena i turizma kroz promjene na razvoj pojedinih turističkih destinacija}

Uz brojne druge učinke, „klimatske promjene mogu bitno promijeniti dugoročne izglede razvoja turizma i njegovih ekonomskih impulsa za pojedine zemlje, regije i svijet u cjelini". ${ }^{79}$. Klima postaje osnovni činitelj kada se definira destinacija za odmor, a povezana je $s$ 
dokolicom, utjecajem na zdravlje i turističkim doživljajem i zadovoljstvom. Zbog tih razloga klima je stavljena na mjesto koje znatno definira atraktivnost destinacije. Tradicionalno se u literaturi navodilo da je turističku destinaciju moguće promatrati kroz njezine sastavne elemente i fiksne i varijabilne čimbenike. Kao fiksne čimbenike navodilo se slike krajolika, znamenitosti, turističku suprastrukturu i sl., hotele, objekte za zabavu, kulturne objekte, turističke urede itd. Unutar njih govorilo se o razlikovanju prema lokalno internim mogućnostima, u koje se ubrajala i klima, i prema lokalno eksternim mogućnostima, u koje su se ubrajale npr. manifestacije. Međutim, danas je sve upitnija opravdanost uvrštavanja klime u grupu fiksnih elemenata, budući da su klimatske promjene iznimno brze i donose izazove u relativno kratkim razdobljima. ${ }^{71}$

Brojne su promjene koje će klimatske promjene izazvati na određenim destinacijama, pri čemu se najčešće ističe da će povećanje temperature dovesti do promjene sezonalnosti, što može biti i prednost u nekim krajevima zbog produljenja sezone ili razvoja turizma u krajevima i destinacijama u kojima turizam nije bilo moguće razvijati zbog nepovoljne klime. Međutim, povećanje temperature može dovesti i do ekonomskih opterećenja povezanih s povećanim troškovima hlađenja i klimatizacije, ali i zbog promjena atraktivnosti lokacije uslijed promjena flore i faune ili promjena klime u kojoj boravak ljudi postane otežan. Nadalje, porast razine temperature mora može dovesti do smanjenja atraktivnosti zbog pojačanog cvjetanja, ali i smanjenja raznolikosti morske flore i faune, što može dovesti i do otežanog ili smanjenog interesa za ronilački turizam. Porast razine mora zbog porasta temperature vode ali i globalnog topljenja ledenjaka dovodi do smanjenja atraktivnosti destinacije zbog gubitka plažnih prostora i erozije obalne infrastrukture. Smanjenje padalina u pojedinim destinacijama može dovesti do poremećaja u opskrbi vodom ili problema s održavanjem ozelenjenih površina ili usporavati ili potpuno onemogućiti razvoj golfskog turizma. Navedene erozije mogu dovesti i do gubitka arheološke imovine, čime se smanjuje atraktivnost prostora. Pojava temperaturnih ekstrema vodi i u klimatološke ekstreme koji mogu rezultirati pojačanjem frekvencija i intenziteta ekstremnih oluja koje dovode do uništavanja turističke infrastrukture, mogućih poplava i požara s istim posljedicama - degradacijom atraktivnih krajolika i smanjenjem dolaska gostiju budući da se gubi atraktivnost destinacija kojoj su upravo prirodne ljepote, bioraznolikost flore i faune i atraktivnost kulturne baštine bili pokretač i atraktant. ${ }^{93}$
Utjecaj klimatskih uvjeta na turističku ponudu kroz atraktivnost destinacija, poglavito na njezin operativni dio, bio je predmet istraživanja u nizu zemalja i različitim tipovima destinacija. Dominantna su istraživanja povezana s najvulnerabilnijim područjima, a to su otoci i otočja, obalni prostori i planinski predjeli pod snijegom.

\section{Destinacije vezane uz planine, snijeg i alpska područja}

Vrijeme i klima sastavni su dio turističkog iskustva te utječu na turističku potražnju, udobnost i zadovoljstvo, kao i na vodoopskrbu, troškove energije, troškove osiguranja, ali i na ekološke resurse koji su kritični za industriju (npr. ledenjaci, bioraznolikost, vodostaj, snijeg). Promjena klime ima potencijal znatno utjecati na ovu gospodarski važnu i klimatski osjetljivu gospodarsku aktivnost. Znatan učinak klimatskih promjena očekuje se u planinskim destinacijama koje su važne za globalni turizam. Segment zimskog turizma, a posebno skijaška industrija, određen je kao jedna od najranjivijih industrija za klimatske promjene. Snježni pokrivač i planinski krajobrazi atrakcije su za turizam u tim regijama, ali su ujedno veoma osjetljive na klimatske promjene.

Turizam je ključni stup gospodarstva u alpskim zemljama, koji godišnje generira oko 50 milijardi eura u alpskoj regiji i pruža $10 \%$ do $12 \%$ radnih mjesta. ${ }^{100}$ Prema Becken i Hay, europske Alpe stvaraju oko 10\% godišnjega globalnog prihoda od cjelogodišnjeg turizma, a oko 100 milijuna turista godišnje posjeti Alpe. ${ }^{48}$ Mnoge su planinske i zimske turističke destinacije u europskim Alpama među najčešće posjećivanim regijama na svijetu. Mnogi oblici alpskog zimskog turizma ovise o aktivnostima na snijegu. $U$ mnogim ruralnim područjima zimski turizam postao je primarni izvor prihoda. ${ }^{101}$ Usredotočenost na aktivnosti ovisne o snijegu čini alpski zimski turizam vrlo osjetljivim na učinke tekućeg trenda zagrijavanja. ${ }^{102,63}$

Zimska turistička djelatnost identificirana je kao rizična zbog jasne povezanosti između klimatskih uvjeta i raspoloživosti prirodnoga snijega, kao i uvjeta za stvaranje umjetnoga snijega koji je ne samo upitno atraktivan nego i neupitno neekološki, jer je koncept umjetnog snijega znatan potrošač energije i time dodatno pridonosi povećanju ugljikova otiska od strane turizma. Zbog toga su regionalne projekcije klimatskih promjena za Europu i Alpe ključne za procjenu budućnosti turizma temeljenog na snijegu. Istraživanja pokazuju da klima već sada utječe na atraktivnost planinskog okoliša u raznim zimskim turističkim destinacijama, a projekcije za bu- 
dućnost govore da će imati znatan utjecaj na skijališni turizam, ali i na turizam baziran na prirodnim ljepotama prvenstveno zbog smanjenja njihove atraktivnosti. ${ }^{21}$

Posebno su osjetljive europske Alpe, ${ }^{101}$ koje se smatraju ,jednim od najranjivijih područja s obzirom na klimatske promjene". ${ }^{100}$ Srednja temperatura ove regije porasla je za do $2{ }^{\circ} \mathrm{C}$ za neka mjesta na visokoj nadmorskoj visini u razdoblju od 1900. do 1990. godine u odnosu na porast od $0,78{ }^{\circ} \mathrm{C}$ u posljednjih 100 godina na globalnoj razini. S određenim stupnjem lokalne varijabilnosti, glečeri su izgubili 50\% svojeg volumena od 1850. godine, a snježni se pokrivač smanjuje, osobito na najnižim visinama te u jesen i proljeće. Očekuju se znatne promjene u planinskim destinacijama zbog pomicanja snježne granice prema većim visinama. Ako dođe do predviđenog pomicanja granice snijega za $300 \mathrm{~m}$, visinska granica sigurnog snijega bila bi pomaknuta na $1500 \mathrm{~m}$ te bi time došlo do skraćenja sezone za mjesec dana u sadašnjim destinacijama. Za svako povećanje temperature od $1{ }^{\circ} \mathrm{C}$ procjenjuje se da će biti oko 14 dana skijanja manje. Pomicanje granice dovelo bi do „smanjenja sadašnjih $85 \%$ skijališta sa sigurnim snijegom na samo $63 \%$ u budućnosti, nakon 2020. godine". ${ }^{102}$ Sezonski pad potražnje zbog nepovoljnih uvjeta ima „ozbiljne ekonomske posljedice za skijaška područja i povezana naselja, uključujući smještaj, poduzeća i druge prateće usluge". ${ }^{102}$

Pojedine studije predviđaju da će u Kanadi i Rusiji doći i do 30-postotnog povećanja turizma ako se temperatura poveća za samo $1^{\circ} \mathrm{C}$, dok će se planinske regije kao što su npr. Alpe, koje se oslanjaju na snijeg za zimsku rekreaciju, suočiti sa znatnim padom dohotka. ${ }^{40}$

Empirijska istraživanja u Sjevernoj Americi potvrdila su da su „minimalna i maksimalna temperatura, dubina snijega i hladnoća vjetra statistički povezani s prodajom karata za skijaške žičare". ${ }^{103}$ Istraživanja u Finskoj pokazala su da je „vjetar bio najčešći razlog zatvaranja skijaških terena, dok su motorne sanjke i skijaško trčanje najviše ometali ledeni uvjeti”. ${ }^{104}$ Loše vrijeme kao važan izvor nezadovoljstva identificirano je u istraživanju posjetitelja Škotske. ${ }^{105,} 106$ U Australiji skijaška sezona traje tek 60 do 70 dana, što se smatra minimumom za održivost, ${ }^{107}$ a ako se ostvare scenariji s visokim emisijama, očekuje se da će temperature u australskim Alpama do 2020. porasti za $1^{\circ} \mathrm{C}$, što bi rezultiralo „smanjenjem trajanja skijaške sezone za 60\%". ${ }^{108}$ Fukushima je predviđao da „kada bi došlo do povećanja temperature u Japanu za $3^{\circ} \mathrm{C}$, došlo bi do smanjenja posjetitelja motiviranih skijanjem za 30\%". ${ }^{109}$
McBoyle i Wall upotrijebili su scenarij podvostručenja količine atmosferskog $\mathrm{CO}_{2}$ kako bi modelirali smanjenje duljine skijaške sezone u Kanadi. ${ }^{110}$ Neki autori prognozirali su pad između $30 \%$ i $40 \%$ za područje na sjeveru obale jezera Superior, zatim pad između $80 \%$ i $100 \%$ za južnu regiju Velikih jezera u blizini zaljeva Georgian, a primjenom iste metodologije procjenjuju se da će se broj skijaških dana smanjiti npr. za između 30\% i 100\% u Michiganu u SAD-u, ${ }^{111}$ ali i u mnogim drugim dijelovima američkog kontinenta poput Vermonta. ${ }^{110}$

Težina učinaka u pojedinim turističkim regijama i destinacijama uvelike će ovisiti o njihovoj individualnoj sposobnosti prilagodbe na klimatske promjene. Promjena klime ima i indirektan učinak na destinacije s obzirom na to da vremenski uvjeti posebice zimi mogu biti povezani s kašnjenjima u prijevozu, otkazima i nesrećama. Također, hladne zime povezane su s većim prometnim nezgodama, dok zime toplije nego inače smanjuju vjerojatnost nezgoda. ${ }^{111}$

Među mnogim važnim poslovnim, strukturnim i tehnološkim prilagodbama, široko prihvaćanje proizvodnje snijega, prema Steigeru i Mayeru, bilo je jedno od najvažnijih ulaganja u skijališta koja su napravljena u cilju osiguravanja njihove ekonomske održivosti. ${ }^{112}$ Brojne druge strategije prilagodbe postale su popularne, uključujući i izgradnju skijališta na višim visinama, ulaganja u smještaj prilagođen aktivnostima za sva godišnja doba, pružanje aktivnosti koje nisu bazirane na snijegu i pružanje atmosfere za druženje nakon skijanja. Unatoč tehnološkom napretku u strojevima i primjeni u proizvodnji snijega te modernizaciji poslovnih planova, čak i najsofisticiranije strategije prilagodbe još uvijek ne mogu pružiti zaštitu skijalištima od trenutačnih i očekivanih utjecaja klimatskih promjena.

Pojedini se autori, kao što su Varlay i Medway, ${ }^{106}$ analizom destinacije Cairngorm zalažu za „redefiniranje alpskog skijaškog turizma i preorijentiranje na ekoturizam" i primjenu ekozofije u turizmu po načelima filozofa i bioetičara Arne Næssa. ${ }^{113}$ lako su autori svjesni da je zasad malo vjerojatno da će se čisti ekozofski turizam dogoditi u bliskoj budućnosti zbog promjene u načinu razmišljanja i pristupa koji će zahtijevati turistička djelatnost, sam Næss tvrdio je da je, ,iako je pesimističan za 21. stoljeće koje se tiče njegove ekozofije, ostao optimist 22. stoljeća". ${ }^{114}$ 


\section{Destinacije vezane uz priobalna područja, otoke i more}

Prema Šverko Grdić, „u priobalnim i otočnim destinacijama klimatske promjene dovodit će do gubljenja atraktivnosti tih prostora, između ostalog i zbog povećanja intenziteta i frekvencije ekstremnih događaja poput povećanja razine mora, promjena u strujama oceana i promjenama u prirodnim ekosustavima, zatim pojavama ekstremnih zračnih struja, pogoršanja UV indeksa, povećanja temperature, nestanka određene turističke infrastrukture, nedostatka pitke vode i slično". ${ }^{11}$

Utjecaj klimatskih promjena na bioraznolikost i prirodni okoliš može negativno djelovati na njegovu vrijednost za turiste. Sve ove promjene u ekosustavu indirektno mogu djelovati na turizam, posebno na one destinacije gdje je priroda glavna atrakcija za turiste. Tako će gradovi s bogatom prirodnom baštinom u budućnosti biti jako osjetljivi, što će negativno utjecati na turizam. Prirodno zaštićen okoliš često je veoma važan za turizam, s obzirom na to da turiste privlače nacionalni parkovi i rezervati netaknute divljine koji nas povezuju s našim iskonskim porijeklom uz koji nas veže naš „,pleistocenski gen”. Antropogeni utjecaj doveo je do početka šestog velikog izumiranja, tako je od 1500 . do 2014. godine zabilježeno 279 izumrlih vrsta sisavaca, od čega ih je 198 izumrlo od 1900. do 2014. godine, što predstavlja gubitak od gotovo dvije vrste godišnje.

Prema IUCN-u, glavni su uzroci ugroženosti bioraznolikosti nestanak i degradacija staništa, unošenje invazivnih vrsta, prekomjerna eksploatacija prirodnih resursa, onečišćenje i bolesti te antropogeno uzrokovane klimatske promjene. ${ }^{115}$ Smanjenju bioraznolikosti znatno pridonose siromaštvo i nedostatak obradivih površina u zemljama u razvoju koji često vode prema krčenju tropskih šuma. Kako ljudska populacija na tim područjima raste, potrebe za hranom su sve veće, a time i potrebe za novim obradivim površinama, što za posljedicu ima daljnje uništavanje i degradaciju staništa. Deforestacija utječe na vrijeme i klimu na lokalnoj, regionalnoj i globalnoj razini, dok antropogena aktivnost mijenja i kemiju okoliša.

\section{Posljedice međuutjecaja klimatskih promjena i turizma na primjeru Hrvatske kao destinacije}

Za malu zemlju kao što je Hrvatska i za njezin turizam koji generira znatan dio društvenog proizvoda čini se opravdano propitivati opisano međudjelovanje turizma i klimatskih promjena u cilju poduzimanja primjerenih radnji i aktivnosti koje će osigurati nesmetan razvoj turizma i u promjenjivim klimatskim uvjetima. ${ }^{79}$ Promjene klimatskih parametara donijet će nove uvjete u poslovanju turističkih subjekata pa je potrebno širiti saznanja o ublažavanju, a posebice o prilagodbi turizma tim promjenama.

U budućim turističkim pravcima bilo kakve klimatski uvjetovane promjene imat će znatne implikacije na receptivne destinacije, pa time i Hrvatsku. Tako se za turiste iz sjeverne i srednje Europe, koji su sada glavni međunarodni turisti, a pripadaju i najbrojnijoj skupini turista koji posjećuju Hrvatsku, očekuje da će trošiti više slobodnog vremena u svojoj zemlji ili u susjedstvu i tako prilagođavati svoje putničke modele na destinacije bliže svojim kućama. ${ }^{116}$ Radova koji bi se bavili proučavanjem međuodnosa klime i turizma u Hrvatskoj je vrlo malo i uglavnom su vezani uz istraživanja manje grupe autora. ${ }^{117-120}$

Republika Hrvatska jest zemlja osjetljiva na klimatske promjene, osobito zbog duljine obalne linije od $5800 \mathrm{~km}, \mathrm{~s} 1185$ otoka, važnosti poljoprivrede, šumarstva i njihovog sociogospodarskog značenja te mogućeg utjecaja na hidrologiju, vodna bogatstva, kopneni i obalni ekosustav. Učinci klimatskih promjena, kao što su povišene temperature, porast razine mora, veći slučajevi olujnog vremena i promjene obrasca bolesti sigurno će utjecati na posebnost hrvatskog turizma, međutim, razmjeri učinaka ovisit će o budućem porastu temperature.

Model koji su razvili Šverko Grdić i Krstinić Nižić pokazuje da „temperatura utječe na broj turista u priobalnom i planinskom dijelu Hrvatske, dok u kontinentalnom dijelu (Zagreb) temperatura ne utječe na turistički tijek". ${ }^{120}$ Iz tih rezultata može se zaključiti da će u ljetnim mjesecima klimatske promjene smanjiti potražnju u priobalnom dijelu i povećati potražnju u sjevernim dijelovima (planinskim područjima) Hrvatske. Isto tako, zbog istih razloga, klimatske promjene poboljšat će predsezonu i postsezonu u priobalnom dijelu. Turistička ponuda na obalnom području područja otoka, planine i kontinentalna Hrvatska morat će se prilagoditi klimatskim promjenama i uvesti nove turističke proizvode. Očekuje se da će hrvatski turizam znatno povećati svoju raznolikost, ponuditi novi asortiman proizvoda i usluga te poboljšati kvalitetu svoje turističke ponude i prepoznati nove trendove u ponašanju suvremenih turista, što uključuje veće zanimanje za bližu i sigurniju destinaciju, povećanje kraćih i češćih putovanja, sve veći interes za kulturna događanja i aktivna putovanja. ${ }^{120}$ 
Europski parlament objavio je infografiku o okolišnim, ekonomskim i zdravstvenim učincima klimatskih promjena na europski kontinent ovisno o pojedinoj regiji, a budući da se Republika Hrvatska zbog svoje geografske raznolikosti i slojevitosti proteže preko čak tri regije: mediteranske, planinske i kontinentalne, očekivani učenici klimatskih promjena u svakoj pojedinoj regiji zahvatit će i Hrvatsku.

U mediteranskoj regiji okolišne posljedice bit će povezane $s$ toplinskim ekstremima. Očekuje se smanjen vodostaj rijeka i smanjene padaline, uz povećani rizik od ugroze bioraznolikosti, učestaliju pojavu suša i požara. Navedene promjene dovest će do povećane tržišne kompetitivnosti oko izvora pitke vode. Naime, povećana količina vode potrebne za poljoprivredu natjecat će se s povećanim potrebama za vodom u turizmu. Zbog nedostatka vode urod će biti smanjen, a uzgoj životinja postat će otežan. Cijela regija ovisit će o dovoljnoj količini i proizvodnji energije od koje će se sve više trošiti na povećane potrebe u rashlađivanju.

U planinskoj regiji temperature će se dizati iznad vrijednosti europskog prosjeka, flora i fauna pomicat će se prema višim predjelima uz visok rizik od izumiranja vrsta, povećat će se opasnost za opstanak šuma, deforestaciju će pratiti veći rizik od odrona kamenja i klizišta tla.

Konačno, u kontinentalnoj regiji temperaturni valovi postat će ekstremniji, kiše će biti manje ljeti, a rizik od šumskih požara i poplava postat će iznimno visok. ${ }^{121}$

\section{Zaključak - perspektive održivog razvoja primjenom mjera ublažavanja i prilagođavanja}

Klimatske promjene imale su znatan utjecaj na putovanja i turizam kroz povijest. Međutim, u novije doba, više nego ranije, klimatske su promjene globalnog karaktera i ozbiljno determiniraju razvoj i budućnost turizma u širem obuhvatu turističkih regija i svijeta u cjelini. Klimatske promjene ne predstavljaju samo jedinstveni izazov za čovječanstvo nego utječu na sve aspekte ljudskog života, uključujući turizam, ali i postaju globalni ekološki problem.

Posljedice klimatskih promjena različito će se manifestirati u različitim područjima, a razmjeri ovise o primije- njenim strategijama borbe protiv klimatskih promjena, od kojih su najvažnije ublažavanje i prilagođavanje. ${ }^{112}$ Ulažu se veliki napori na globalnoj razini u cilju ublažavanja posljedica klimatskih promjena te poduzimanja mjera u sprječavanju daljnjih negativnih posljedica koje bi u budućnosti mogle biti nepopravljive. ${ }^{60}$

Ublažavanje klimatskih promjena i sprječavanje negativnih utjecaja na okoliš jedan su od najvažnijih zadataka čovječanstva.

Strategija ublažavanja ima za cilj smanjenje štetnih emisija u atmosferu te na taj način ublažavanje efekta staklenika. Mjere ublažavanja posljedice klimatskih promjena rjeđe su dobrovoljne. a učinkovitije su ako budu potaknute ekonomskim i regulatornim instrumentima. ${ }^{90}$

lako ublažavanje ovisi o tehnološkim, ekonomskih i socijalnim promjenama, izazov se sastoji u potrebi da dođe do promjene ponašanja i strukturnih promjena. ${ }^{4}$ Konačni je cilj smanjenje potrošnje dobara koja svojim izgaranjem uzrokuju intenzivno ispuštanje $\mathrm{CO}_{2} \mathrm{u}$ atmosferu.

Najvažnije strategije vežu se za smanjenje korištenja energije, poboljšanje energetske efikasnosti, povećanje korištenja obnovljivim izvorima energije i smanjenje emisija $\mathrm{CO}_{2}$ kroz ugljikove ispuste.

Ublažavanje posljedice klimatskih promjena podrazumijeva sve napore zajednice na smanjivanju stvaranja efekta staklenika u nadi da će tako biti reducirana količina i brzina klimatskih promjena. Riječ je o cijelom spektru mjera koje uključuju poboljšanu učinkovitost opskrbe i distribucije energije, promjene na zeleniji izvor goriva, promjene načina transporta, izgradnju biciklističkih staza, elektrovozila u prijevozu unutar resorta, upotreba vozila s manjim emisijama, zahvate na građevinama koji uključuju učinkovitije uređaje za grijanje i hlađenje, povećanje energetske učinkovitosti, smanjenje toplinskih gubitaka, bolju izolaciju, korištenje danjeg i Sunčeva svjetla, obnovu topline i energije, upotrebu biomase kao energenta, povećanje energetske učinkovitosti, raznovrsne promjene u načinu proizvodnje i distribucije hrane, orijentaciju na organski uzgoj i slično.

Potrošači mogu pridonijeti ublažavanju štetnog utjecaja turizma na klimu kroz promjenu ponašanja koja uključuje promjene sadašnjeg trenda češćeg putovanja s kraćim ostancima u destinaciji prema rjeđim putovanjima $s$ duljim trajanjima, minimalizaciju upotrebe avioprijevoza, favoriziranje proekoloških operatera i 
agencija, davanje prednosti certificiranim i ekološki prijateljskim destinacijama.

Mjere prilagodba vrlo su važne u smanjivanju ranjivosti na klimatske promjene i važan su način rješavanja problema negativnih utjecaja klimatskih promjena u sljedećih nekoliko desetljeća. ${ }^{4}$ Mjerama prilagodbe pokušava se identificirati korake koji se mogu poduzeti kako bi se ograničile nepovoljne posljedice, a kako bi se društvo u cjelini, a onda i turizam koji je vrlo važna gospodarska aktivnost, na vrijeme i što uspješnije pripremili za nove uvjete poslovanja te kako bi se u najvećoj mogućoj mjeri izbjegli mogući negativni učinci klimatskih promjena i što je više moguće iskoristili oni pozitivni koji će se u budućnosti događati. Prilagođavanje je praktičan način navikavanja na trenutačne klimatske promjene i ekstremne događaje, kao i prilagodba na dugotrajnije klimatske promjene.

Pod prilagodbom se može smatrati prilagodba prirodnog ili ljudskog sustava na sadašnje ili očekivane klimatske promjene koja je motivirana ekonomskim, socijalnim ili okolišnim činiteljima. ${ }^{86}$

Ozbiljnost učinaka u pojedinim turističkim regijama i odredištima će uvelike ovisiti o njihovoj individualnoj sposobnosti prilagodbe na klimatske promjene. Adaptacija u kontekstu klimatskih promjena odnosi se na prilagodbe u ekološko-socioekonomskim sustavima kao odgovor na stvarne ili očekivane klimatske podražaje, njihove učinke ili utjecaje. ${ }^{123}$ Prilagodbe mogu biti anticipatorne (uzete proaktivno prije klimatskog poticaja), istodobne (tijekom) ili reaktivne (kao odgovor). Na temelju njihovog stupnja svrhovitosti, Smit i suradnici razlikuju autonomne (spontane) i planirane (namjerne) adaptivne odgovore na stvarni ili očekivani poticaj. Prilagodbe u društveno-ekonomskim sustavima često su reaktivne prirode, pri čemu postoji mnogo različitih oblika prilagodljivih odgovora na klimatske promjene. ${ }^{123}$ Autori razlikuju primarno tehnološke, ponašajne, financijske, institucionalne i informacijske prilagodbe, ${ }^{123}$ dok drugi daju klasifikaciju tehničkih, ekonomskih, političkih, institucionalnih, upravljačkih, planskih, pravnih i bihevioralnih klimatskih prilagodbi. ${ }^{63}$ Učinkovita prilagodba smanjuje osjetljivost regije na klimatske promjene. Na lokalnoj ili regionalnoj razini potencijal prilagodbe sustava nije određen samo ekonomskim i tehničkim resursima, već i čimbenicima kao što su menadžerske sposobnosti ili pristup informacijskim resursima. ${ }^{124}$ Jedan je od čimbenika koji će utjecati na prilagodbu turističkih uvjeta klimatskim promjenama fleksibilnost institucija čije odluke utječu na turizam. Vrijeme održavanja državnih praznika, školskih praznika, lovnog i ribolovnog razdoblja, datumi otvaranja i zatvaranja parkova i drugih turističkih atrakcija mogu se promijeniti u novim klimatskim okolnostima. ${ }^{90}$ Opažanja dionika još su jedan ključni aspekt u smanjenju ranjivosti na klimatske promjene. Osviještenost ključnih igrača o klimatskim promjenama određuje poduzima li se djelotvorna akcija, ${ }^{125,126}$ Procjene dionika o mogućem opsegu i učincima prijetnje su odlučujuće za shvaćenu potrebu prilagodbe u regiji. Prema Belle i Bramwellu, percepcije pojedinaca i interesnih skupina također su ključne za razvoj javnih politika i prihvaćanje predloženih mjera politike. U skladu s time, učenje kako živjeti s promjenama i neizvjesnošću posljedica je toga koliko dobro dionici u regiji vide potencijalne izazove. ${ }^{125}$ U kontekstu istraživanja klimatskih promjena, studije percepcije rizika među dionicima od vitalne su važnosti za procjenu ranjivosti regije na klimatske promjene. Možda upravo zbog nedovoljne percepcije rizika identificirano je samo $2 \%$ turističkih tvrtki na globalnoj razini koje sudjeluju u inicijativama odgovornog turizma kao način odgovora na prijetnju klimatskih promjena. ${ }^{127}$

Za malu zemlju kao što je Hrvatska i za njezin turizam koji generira iznimno važan dio društvenog proizvoda te na neki način o prihodima od turizma ovisi i uobičajeno funkcioniranje države, čini se opravdano propitivati opisano međudjelovanje turizma i klimatskih promjena prilikom planiranja i poduzimanja primjerenih radnji i aktivnosti koje će osigurati nesmetan razvoj turizma i u promjenjivim klimatskih uvjetima.

Uspješnost prilagodbi ovisi će također o mogućnosti i kapacitetu prilagodbe. Nedvojbeno je da će implementacija prilagodbe biti moguća tek uz znatna financijska sredstva, međutim njezin je cilj smanjiti osjetljivost i negativne efekte klimatskih promjena. ${ }^{99}$ 


\section{Reference}

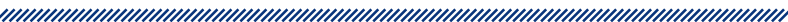

1. Pachauri RK, Meyer LA, ur. IPCC. Climate Change 2014: Synthesis Report. Contribution of Working Groups I, II and III to the Fifth Assessment Report of the Intergovernmental Panel on Climate Change, Ženeva : IPCC, 2014. Dostupno na: https://www.ipcc.ch/site/assets/ uploads/2018/02/SYR_AR5_FINAL_full.pdf

2. Branković Č. Klima i klimatske promjene. Matematičkofizički list 3.255 (2014): 152-162. Dostupno na: https:// bib.irb.hr/datoteka/696272.brankovic.pdf

3. LZ Miroslav Krleža. Efekt staklenika. u: Hrvatska enciklopedija, online izdanje. Zagreb: Leksikografski zavod Miroslav Krleža, 1999. - 2009. Dostupno na: http://www. enciklopedija.hr//natuknica.aspx?ID=17109

4. Perić J, Šverko Grdić Z. Climate change and tourism. Opatija: Fakultet za menadžment u turizmu i ugostiteljstvu, 2017.

5. Zaninović K, et al. Klimatski atlas Hrvatske Zagreb: Državni hidrometeorološki zavod, 2008.

6. DHMZ. Sedmo nacionalno izvješće Republike Hrvatske prema Okvirnoj konvenciji Ujedinjenih naroda o promjeni klime, DHMZ: Zagreb, 2018. Dostupno na: http:// klima.hr/razno/publikacije/NIKP7_DHMZ.pdf

7. Leiserowitz A. International public opinion, perception, and understanding of global climate change. Human development report 2008 (2007): 1-40. Dostupno na: https://core.ac.uk/download/pdf/6248846.pdf

8. Ančić Branko, Puđak J, Domazet M. Vidimo li klimatske promjene u Hrvatskoj? - istraživanje stavova o nekim od aspekata klimatskih promjena u hrvatskom društvu. Hrvatski meteorološki časopis 51.51 (2016): 27-45. Dostupno na: http://hrcak.srce.hr/168219

9. Amelung B, Nicholls S, Viner D. Implications of global climate change for tourism flows and seasonality. Journal of Travel Research 45.3 (2007): 285-296. Dostupno na: http://journals.sagepub.com/doi/abs/10.1177/0047287506295937

10. Fleurbaey $M$, et al. Sustainable development and equity. U: Edenhofer $O$ et al., ur. Climate change 2014: mitigation of climate change. Working group III contribution to the fifth assessment report of the Intergovernmental $\mathrm{Pa}$ nel on Climate Change, New York: Cambridge University Press, 2014. 238-350.

11. IPCC, Summary for Policymakers. In: Global Warming of $1.5^{\circ} \mathrm{C}$. An IPCC Special Report on the impacts of global warming of $1.5^{\circ} \mathrm{C}$ above pre-industrial levels and related global greenhouse gas emission pathways, in the context of strengthening the global response to the threat of climate change, sustainable development, and efforts to eradicate poverty edited by V. Masson-Delmotte et al. 1-32. Ženeva: World Meteorological Organization, 2018.

12. Albert $\mathrm{S}$, et al. Heading for the hills: climate-driven community relocations in the Solomon Islands and Alaska provide insight for a $1.5 \mathrm{C}$ future. Regional environmental change 18.8 (2018): 2261-2272. Dostupno na: https://link. springer.com/article/10.1007\%2Fs10113-017-1256-8

13. Edvardsson Björnberg K, et al. Climate and environmental science denial: A review of the scientific literature published in 1990-2015. Journal of Cleaner Production 167 (2017): 229-241. Dostupno na: https://doi.org/10.1016/j. jclepro.2017.08.066

14. Engels A, et al. Public climate-change skepticism, energy preferences and political participation. Global environmental change 23.5 (2013): 1018-1027. Dostupno na: https://doi.org/10.1016/j.gloenvcha.2013.05.008

15. Leviston Z, Walker I. Beliefs and denials about climate change: An Australian perspective. Ecopsychology 4.4 (2012): 277-285. Dostupno na: https://doi.org/10.1089/ eco.2012.0051

16. Poortinga $\mathrm{W}$, et al. Uncertain climate: An investigation into public scepticism about anthropogenic climate change. Global environmental change 21.3 (2011): 10151024. Dostupno na: http://orca.cf.ac.uk/11295/1/Uncertain\%20climate\%2010.1016j.gloenvcha.2011.03.001.pdf

17. McCright AM, Dunlap RE. Cool dudes: The denial of climate change among conservative white males in the United States. Global environmental change 21.4 (2011): 1163-1172. Dostupno na: https://doi.org/10.1016/j.gloenvcha.2011.06.003

18. Ojala M. Climate change skepticism among adolescents. Journal of Youth Studies 18.9 (2015): 1135-1153. Dostupno na: https://doi.org/10.1080/13676261.2015.1020927

19. Sarkki S, Karjalainen TP. Ecosystem service valuation in a governance debate: Practitioners' strategic argumentation on forestry in northern Finland. Ecosystem services 16 (2015): 13-22. Dostupno na: https://doi.org/10.10 80/2154896X.2012.679564

20. Stoll-Kleemann S. Reconciling opposition to protected areas management in Europe: the German experience. Environment: Science and Policy for Sustainable Development 43.5 (2001): 32-44. Dostupno na: https://www. tandfonline.com/doi/abs/10.1080/00139150109605145

21. Stoll-Kleemann S, O'Riordan T, Jaeger CC. The psychology of denial concerning climate mitigation measures: evidence from Swiss focus groups. Global environmental change 11.2 (2001): 107-117. Dostupno na: https://doi. org/10.1016/S0959-3780(00)00061-3

22. Poberezhskaya M. Media coverage of climate change in Russia: Governmental bias and climate silence. Public Understanding of Science 24.1 (2015): 96-111. Dostupno na: https://doi.org/10.1177\%2F0963662513517848

23. Asayama S, Ishii A. Reconstruction of the boundary between climate science and politics: The IPCC in the Japanese mass media, 1988-2007. Public Understanding of Science 23.2 (2014): 189-203. Dostupno na: https://doi. org/10.1177\%2F0963662512450989

24. Lo AY. Political ambiguity in Chinese climate change discourses. Environmental Values 24.6 (2015): 755-776. Dostupno na: https://doi.org/10.3197/096327115X14420732702653 
25. Živojinović I, Wolfslehner B. Perceptions of urban forestry stakeholders about climate change adaptation-A Q-method application in Serbia. Urban forestry \& urban greening 14.4 (2015): 1079-1087. Dostupno na: https:// doi.org/10.1016/j.ufug.2015.10.007

26. Diethelm P, McKee M. Denialism: what is it and how should scientists respond? The European Journal of Public Health 19.1 (2009): 2-4. Dostupno na: https://doi. org/10.1093/eurpub/ckn139

27. Kraft PW, Lodge M, Taber CS. Why people „don't trust the evidence" motivated reasoning and scientific beliefs. The ANNALS of the American Academy of Political and Social Science 658.1 (2015): 121-133. Dostupno na: https://doi.org/10.1177/0002716214554758

28. ZhouM.Publicenvironmental skepticism:Across-nationaland multilevel analysis. International Sociology 30.1 (2015): 6185. Dostupno na: https://doi.org/10.1177/0268580914558285

29. Whitmarsh L. Scepticism and uncertainty about climate change: Dimensions, determinants and change over time. Global environmental change 21.2 (2011): 690-700.

30. Doran PT, Kendall Zimmerman M. Examining the scientific consensus on climate change. Eos, Transactions American Geophysical Union 90.3 (2009): 22-23. Dostupno na: https://doi.org/10.1029/2009E0030002

31. Patt A. Assessing model-based and conflict-based uncertainty. Global Environmental Change 17.1 (2007): 37-46. Dostupno na: https://doi.org/10.1016/j.gloenvcha.2006.10.002

32. Hulme M. Why we disagree about climate change: Understanding controversy, inaction and opportunity. Cambridge University Press, 2009. Dostupno na: http://www.kvccdocs.com/KVCC/2014-Spring/SOC101/ content/L-29/climate-change.pdf

33. Sjöberg L. Risk perception is not what it seems: The psychometric paradigm revisited. Valdor conference. Stockholm: VALDOR, 2003. Dostupno na: http://www. dynam-it.com/lennart/pdf/valdor3.pdf

34. Downing P, Ballantyne J. Tipping point or turning point? Ipsos-Mori social research institute. (2007): 1-48.

35. Europska komisija. Eurobarometer-Special Eurobarometer 300. Europeans' attitudes towards climate change. Bruxelles: Europska komisija, 2009. Dostupno na: http://ec.europa.eu/ public_opinion/archives/ebs/ebs_300_full_en.pdf

36. Lorenzoni I, Pidgeon NF. Public views on climate change: European and USA perspectives. Climatic change 77.1-2 (2006): 73-95. Dostupno na: https://link.springer.com/ article/10.1007/s10584-006-9072-z

37. Festinger L. A theory of cognitive dissonance. Stanford, CA: Stanford Univ Press, 1957.

38. Lorenzoni I, Nicholson-Cole S, Whitmarsh L. Barriers perceived to engaging with climate change among the UK public and their policy implications. Global environmental change 17.3-4 (2007): 445-459. Dostupno na: https:// doi.org/10.1016/j.gloenvcha.2007.01.004

39. Stern N. The economics of climate change: the Stern review. Cambridge University press, 2007. Dostupno na: http:// www.dse.univr.it/documenti/Avviso/all/all479053.pdf
40. Tucker WC. The Big Lie: Is Climate Change Denial a Crime against Humanity. Interdisciplinary Journal of Human Rights. L. 7 (2012): 91. Dostupno na: https://heinonline.org/HOL/ LandingPage?handle=hein.journals/ijhrl7\&div=7\&id=\&page=

41. Bonacci O. I do not dispute global warming. Građevinar: časopis Hrvatskog saveza građevinskih inženjera 65.6 (2013): 587. Dostupno na: https://hrcak.srce.hr/file/42458

42. Solomon S, et al. Climate change 2007-the physical science basis: Working group I contribution to the fourth assessmentreport of the IPCC.Vol.4.Cambridge:University press, 2007. Dostupno na: https://www.humphreyfellowship. org/system/files/stern_summary___what_is_the_economics_of_climate_change.pdf

43. V, Kufrin K, Puđak J. Kap preko ruba čaše-Klimatske promjene: svijet i Hrvatska. Zagreb: Hrvatski centar „Znanje za okoliš", 2007. Dostupno na: http://ec.europa.eu/environment/ life/project/Projects/index.cfm?fuseaction=home.showFile \&rep=file\&fil=Kapprekorubacase.pdf

44. Krželj M. Impact of climate change on marine environment. Paediatria Croatica. Supplement 54 (2010): 18-23. Dostupno na: https://bib.irb.hr/datoteka/488943.Krelj_Maja.pdf

45. DHMZ. Šesto nacionalno izvješće Republike Hrvatske prema Okvirnoj konvenciji Ujedinjenih naroda o promjeni klime. DHMZ: Zagreb, 2013. Dostupno na: http:// klima.hr/razno/publikacije/NIKP6_DHMZ.pdf

46. Müller H. Turizam i ekologija. Zagreb: Masmedia, 2004.

47. Becken S. The importance of climate and weather for tourism: literature review. Leap, 2010.

48. Schoof C. Ice sheet grounding line dynamics: Steady states, stability, and hysteresis. Journal of Geophysical Research: Earth Surface 112.F3 (2007). Dostupno na: https://doi.org/10.1029/2006JF000664

49. Schoof $C$, et al. Hydraulic switches in the subglacial drainage system. In American Geophysical Union, Fall Meeting 2018, abstract \#C44A-02. (2018). Dostupno na: http://adsabs.harvard.edu/abs/2018AGUFM.C44A.02S

50. Latif M. Izazovi klimatskih promjena-što nam je činiti-sada! Cres: Poduzetništvo Jakić d.o.o., 2008.

51. Hoegh-Guldberg $\mathrm{O}$, et al. Impacts of $1.5^{\circ} \mathrm{C}$ global warming on natural and human systems. (2018). Dostupno na: https://www.ipcc.ch/sr15/chapter/chapter-3/

52. Taylor M, Figgis P. Protected Areas: buffering nature against climate change overview and recommendations. Protected Areas: Buffering nature against climate change 18 (2007): 1. Dostupno na: https://www.preventionweb.net/files/11519_CCreport.pdf\#page=6

53. Tratalos JA, et al. Interactions between tourism, breeding birds and climate change across a regional scale. Mancheser: Tyndall Centre for Climate Change Research, 2005. Dostupno na: https://www.researchgate.net/profile/lan_ Bateman/publication/267990770_Interactions_between_ tourism_breeding_birds_and_climate_change_across_a_ regional_scale/links/54635f540cf2cb7e9da92ad0.pdf

54. Barnosky AD, et al. Has the Earth's sixth mass extinction already arrived? Nature 471.7336 (2011): 51. Dostupno na: https://www.nature.com/articles/nature09678 
55. Jacob D, et al. Climate impacts in Europe under+ $1.5 \mathrm{C}$ global warming. Earth's Future 6.2 (2018): 264-285. Dostupno na: https://agupubs.onlinelibrary.wiley.com/ doi/full/10.1002/2017EF000710

56. Kjellström E, et al. European climate change at global mean temperature increases of 1.5 and 2 degrees $C$ above pre-industrial conditions as simulated by the EUROCORDEX regional climate models. Earth System Dynamics 9.2 (2018): 459-478. Dostupno na: https://www. earth-syst-dynam.net/9/459/2018/

57. Gössling S, Hall CM. Tourism and global environmental change: Ecological, social, economic and political interrelationships. Vol. 4. Taylor \& Francis, 2006. Dostupno na: https://doi.org/10.1111/j.1745-5871.2007.00438.x

58. Španjol Ž. Turizam i zaštita prirode i čovjekova okoliša. Socijalna ekologija: časopis za ekološku misao i sociologijska istraživanja okoline 6.1-2 (1997): 93-108. Dostupno na: https://hrcak.srce.hr/file/208750

59. UNWTO. Tourism Highlights2018Edition, Madrid:UNWTO,2019. Dostupnona:https://doi.org/10.18111/9789284419876UNWTO

60. Michailidou AV, Vlachokostas C, Moussiopoulos N. Interactions between climate change and the tourism sector: Multiple-criteria decision analysis to assess mitigation and adaptation options in tourism areas. Tourism Management 55 (2016): 1-12.

61. Weir B. Climate change and tourism-Are we forgetting lessons from the past? Journal of Hospitality and Tourism Management 32 (2017): 108-114. Dostupno na: https:// doi.org/10.1016/j.jhtm.2017.05.002

62. Scott D, Gössling S, Hall CM. International tourism and climate change. Wiley Interdisciplinary Reviews: Climate Change 3.3 (2012): 213-232. Dostupno na: https://doi. org/10.1002/wcc.165

63. Farid $\mathrm{H}$, et al. Trend of research on sustainable tourism and climate change in 21st century. Worldwide Hospitality and Tourism Themes 8.5 (2016): 516-533. Dostupno na: https://doi.org/10.1108/WHATT-06-2016-0032

64. Gössling S. Global environmental consequences of tourism. Global environmental change 12.4 (2002): 283-302. Dostupno na: https://doi.org/10.1016/S09593780(02)00044-4

65. Gössling S. Human-environmental relations with tourism. Annals of tourism research 29.2 (2002): 539-556. Dostupno na: https://www.sciencedirect.com/science/ article/pii/S016073830100069X

66. Gössling S. Global environmental consequences of tourism. Global environmental change 12.4 (2002): 283-302. Dostupno na: https://doi.org/10.1016/S0959-3780(02)00044-4

67. Gössling S, et al. The eco-efficiency of tourism. Ecological economics 54.4 (2005): 417-434. Dostupno na: https://doi.org/10.1016/j.ecolecon.2004.10.006

68. Gössling S, Peeters P. „It does not harm the environment!" An analysis of industry discourses on tourism, air travel and the environment. Journal of Sustainable Tourism 15.4 (2007): 402-417. Dostupno na: https://doi. org/10.2167/jost672.0
69. Hu Y, Ritchie JRB. Measuring destination attractiveness: A contextual approach. Journal of travel research 32.2 (1993): 25-34. Dostupno na: https://doi.org/10.1177\% 2F004728759303200204

70. Kozak N, Uysal M, Birkan I. An analysis of cities based on tourism supply and climatic conditions in Turkey. Tourism Geographies 10.1 (2008): 81-97. Dostupno na: https://doi.org/10.1080/14616680701825230

71. Šverko Grdić Z. Klimatske promjene i razvoj hrvatskoga turizma. Doktorska disertacija, Opatija: Fakultet za menadžment u turizmu i ugostiteljstvu, Sveučilište u Rijeci, 2012.

72. Gómez Martín MB. Weather, climate and tourism a geographical perspective. Annals of tourism research 32.3 (2005): 571-591. Dostupno na: https://doi.org/10.1016/j. annals.2004.08.004

73. Scott D, Lemieux C. United Nations World Tourism Organization. 2009. Dostupno na: https://doi.org/10.1016/j. proenv.2010.09.011

74. Agnew M, Palutikof JP. Impacts of short-term climate variability in the UK on demand for domestic and international tourism. Climate Research 31.1 (2006): 109-120. Dostupno na: https://www.int-res.com/articles/cr2006/31/ c031p109.pdf

75. LiseW, Tol RSJ. Impact of climate on tourist demand.Climatic change55.4(2002):429-449. Dostupnona:https://link.springer.com/content/pdf/10.1023\%2FA\%3A1020728021446.pdf

76. Dubois G, Ceron JP. Tourism and climate change: Proposals for a research agenda. Journal of Sustainable Tourism 14.4 (2006): 399-415. Dostupno na: https://www. researchgate.net/publication/249023793_Tourism_and_ Climate_Change_Proposals_for_a_Research_Agenda

77. De Freitas CR. The climate-tourism relationship and its relevance to climate change impact assessment. U: Hall HM, Higham J, ur. Tourism, Recreation and Climate Change: International Perspectives. 29-43. Channelview Press, UK, 2005. Dostupno na: http://www.urbanclimate.net/matzarakis/papers/TAC_2012_Sonnblick.pdf

78. Buhalis D, Costa C, ur. Tourism management dynamics: trends, management and tools. Oxford: Routledge, 2006.

79. Perić J, Šverko Grdić Z. Turizam i klimatske promjenedvosmjerna ulica i hijerarhijski model. Ekonomska politika Hrvatske u 2009., 1.1. (2008): 199-214.

80. Patterson T, Bastianoni S, Simpson M. Tourism and climate change: Two-way street, or vicious/virtuous circle? Journal of Sustainable Tourism 14.4 (2006): 339-348. Dostupno na: http://citeseerx.ist.psu.edu/viewdoc/downlo ad?doi=10.1.1.821.1387\&rep=rep1\&type=pdf

81. Hamilton JM, Tol RSJ. The impact of climate change on tourism in Germany, the UK and Ireland: a simulation study. Regional Environmental Change 7.3 (2007): 161-172. Dostupno na: https://kopernio.com/ viewer?doi=10.1007/s10113-007-0036-2\&route=7

82. Berrittella $M$, et al. A general equilibrium analysis of climate change impacts on tourism. Tourism management 27.5 (2006): 913-924. Dostupno na: https://www.fnu.zmaw. de/fileadmin/fnu-files/publication/tol/RM6918.pdf 
83. Bigano A, Hamilton JM, Tol RSJ. The impact of climate change on domestic and international tourism: a simulation study. The Integrated Assessment Journal Bridging Sciences \& Policy 7.1 (2007): 25-49. Dostupno na: https://www.esri.ie/pubs/JACB000029.pdf

84. Pham TD, Simmons DG, Spurr R. Climate change-induced economic impacts on tourism destinations: the case of Australia. Journal of Sustainable Tourism 18.3 (2010): 449-473. Dostupno na: https://www.tandfonline.com/ doi/abs/10.1080/09669581003668532

85. Scott D, Dawson J, Jones B. Climate change vulnerability of the US Northeast winter recreation-tourism sector. Mitigation and adaptation strategies for global change 13.5-6 (2008): 577-596.

86. Scott D, Gössling S, de Freitas CR. Preferred climates for tourism: case studies from Canada, New Zealand and Sweden. Climate Research 38.1 (2008): 61-73. Dostupno na: https://www.int-res.com/articles/cr2009/38/c038p061.pdf

87. Pike S. Destination image analysis - a review of 142 papers from 1973 to 2000 . Tourism management 23.5 (2002): 541-549. Dostupno na: https://doi.org/10.1016/ S0261-5177(02)00005-5

88. Hamilton JM, Lau MA. The role of climate information in tourist destination choice decision making. Working Paper FNU-56. Tourism and global environmental change: Ecological, economic, social and political interrelationships 229. (2005): 1-35. Dostupno na: http://epub.sub.uni-hamburg. de/epub/volltexte/2012/16054/pdf/climinfo_FNU_56.pdf

89. Jopp R, et al. Climate change adaptation: destination management and the green tourist. Tourism Planning \& Development 12.3 (2015): 300-320. Dostupno na: https://doi.org/10.1080/21568316.2014.988879

90. Wall G. Turistička industrija: njena ranjivost i prilagodljivost promjeni klime / The tourism industry: its vulnerability and adaptability to climate change. Acta turistica (2006): 171192. Dostupno na: https://www.jstor.org/stable/23234122

91. Lohmann M, Kaim E. Weather and holiday destination preferences image, attitude and experience. The Tourist Review 54.2 (1999): 54-64. Dostupno na: https://doi. org/10.1108/eb058303

92. Scott D, Lemieux C. United Nations World Tourism Organization. Procedia Environmental Sciences, 1.1 (2010):146-183. Dostupno na: https://doi.org/10.1016/j. proenv.2010.09.011

93. UNDP Hrvatska. Dobra klima za promjene - Klimatske promjene i njihove posljedice na društvo i gospodarstvo u Hrvatskoj. Zagreb: UNDP, 2009. Dostupno na: http:// www.hr.undp.org/content/dam/croatia/docs/Research\%20and\%20publications/environment/UNDP_HR_ ClimateforChange_HR_2008.pdf

94. Gustetić I. Klimatske promjene u svijetu i njihov utjecaj na turizam. Diplomski rad. Rijeka: Fakultet za menadžment u turizmu i ugostiteljstvu, Sveučilište u Rijeci. 2016. Dostupno na: https://repository.fthm.uniri.hr/download-acopy?download_id=a383f9d10d3b6b322fb63ae3183ae566 $7 \mathrm{e} 25101 \mathrm{f} 8 \mathrm{f} 3 \mathrm{a}$
95. Simpson MC, et al. Climate change adaptation and mitigation in the tourism sector: frameworks, tools and practices. Climate change adaptation and mitigation in the tourism sector: Frameworks, tools and practices. Pariz: UNEP, University of Oxford, UNWTO, WMO, 2008. Dostupno na: http://www.unep.fr/shared/publications/ pdf/dtix1047xpa-climatechange.pdf

96. Dwyer L, Forsyth P, Dwyer W. Tourism economics and policy. Vol. 3. Clevedon, Buffalo, Toronto: Channel View Publications, 2010. Dostupno na: https://books.google.hr/ books?hl=hr\&lr=\&id=wv_OBQAAQBAJ\&oi=fnd\&pg=PA17\&ots= NcgfG8VhAr\&sig=_R--uP1CQPrYXYh8cxDD2onhbDo\&redir_ esc=y\#v=onepage \&q\&f=false.

97. Ferriera Lopes SD, Rial Boubeta A, Varela Mallou J. Post hoc tourist segmentation with conjoint and cluster analysis." Pasos, Revista de Turismo y Patrimonio Cultural 7.3 (2009): 491-501. dostupno na: http://www.pasosonline.org/Publicados/7309special/PS0309_12.pdf

98. Hall CM, Higham J. Tourism, recreation and climate change. Clevedon, Buffalo, Toronto: Channel View Publications, 2005.

99. Šverko Grdić Z, Krstinić Nižić M, Mamula M. Povezanost klimatskih promjena i turizma: multikriterijska analiza ocjenjivanja mjera prilagodbe. Ekonomska misao i praksa 1 (2017): 171-185. Dostupno na: https://hrcak.srce.hr/file/270632

100. Bonzanigo L, Giupponi C, Balbi S. Sustainable tourism planning and climate change adaptation in the Alps: A case study of winter tourism in mountain communities in the Dolomites. Journal of Sustainable Tourism 24.4 (2016): 637-652. Dostupno na: https://www.tandfonline. com/doi/full/10.1080/09669582.2015.1122013

101. Abegg B, et al. Climate change impacts and adaptation in winter tourism. Climate change in the European Alps: Adapting winter tourism and natural hazards management (2007): 25-58. Dostupno na: http://www.oecd.org/ env/cc/climatechangeintheeuropeanalpsadaptingwintertourismandnaturalhazardsmanagement.html

102. Scott D, Jones B, Konopek J. Exploring potential visitor response to climate-induced environmental changes in Canada's Rocky Mountain national parks. Tourism Review International 12.1 (2008): 43-56. Dostupno na: https://doi.org/10.3727/154427208785899939

103. Shih C, Nicholls S, Holecek DF. Impact of weather on downhill ski lift ticket sales. Journal of Travel Research 47.3 (2009): 359-372. Dostupno na: https://doi. org/10.1177/0047287508321207

104. Tervo K. The operational and regional vulnerability of winter tourism to climate variability and change: The case of the Finnish nature-based tourism entrepreneurs. Scandinavian Journal of Hospitality and Tourism 8.4 (2008): 317-332. Dostupno na: https://doi. org/10.1080/15022250802553696

105. Smith ER. Social identity and social emotions: Toward new conceptualizations of prejudice. Affect, cognition and stereotyping. Academic Press, 1993. 297-315. Dostupno na: http://www.indiana.edu/ smithlab/articles/ IETCompass.pdf 
106. Varley P, Medway D. Ecosophy and tourism: Rethinking a mountain resort. Tourism Management 32.4 (2011): 902-911. Dostupno na: https://doi.org/10.1016/j.tourman.2010.08.005

107. Galloway RW. The potential impact of climate changes on Australian ski fields. U: Pearlman GI, ur. Greenhouse: Planning for climate change, 428-437. Leiden, New York, Kopenhagen, Köln: Cisro, 1988.

108. Hennessy KJ, et al. Climate change effects on snow conditions in mainland Australia and adaptation at ski resorts through snowmaking. Climate Research 35.3 (2008): 255-270. Dostupno na: https://www.int-res.com/ articles/cr2007/35/c035p255.pdf

109. Fukushima T, et al. Influences of air temperature change on leisure industries - case study on ski activities. Mitigation and Adaptation Strategies for Global Change 7.2 (2002): 173-189. Dostupno na: https://link.springer.com/ content/pdf/10.1023\%2FA\%3A1022803405470.pdf

110. Dawson J, Scott D. Climate change vulnerability of the Vermont ski tourism industry (USA). Annals of Leisure Research 10.3-4 (2007): 550-572. Dostupno na: https:// doi.org/10.1080/11745398.2007.9686781

111. Lipski S, McBoyle G. The impact of global warming on downhill skiing in Michigan. East Lakes Geographer 26 (1991): 37-51.

112. Koetse MJ, Rietveld P. The impact of climate change and weather on transport: An overview of empirical findings. Transportation Research Part D: Transport and Environment 14.3 (2009): 205-221. Dostupno na: https://doi. org/10.1016/j.trd.2008.12.004

113. Steiger R, Mayer M. Snowmaking and climate change. Mountain Research and Development 28.3 (2008): 292299. Dostupno na: dostupno na: https://doi.org/10.1659/ mrd.0978

114. Næss A. The shallow and the deep, long-range ecology movement. Asummary. Inquiry 16.1-4 (1973):95-100. Dostupno na: https://doi.org/10.1080/00201747308601682

115. IUCN. Red list of Threathened Speces, Cambridge, UK: IUCN, 2019. Dostupno na: http://www.iucnredlist.org/ news/biodiversitycrisis

116. Šestan Kučić I. Promjena klime će drastično promijeniti turizam: Sezona će se produljiti, ali će broj gostiju u „špici” biti manji. Novi list, 15. lipnja 2018. Dostupno na: http://novilist.hr:8090/Vijesti/Hrvatska/Promjena-klime-ce-drasticno-promijeniti-turizam-Sezona-ce-se-produljiti-ali-ce-broj-gostiju-u-spici-biti-manji

117. Šverko Grdić Z, Krstinić Nižić M. Development of tourist demand in correlation with climate change in the Repu- blic of Croatia. Ekonomski pregled 67.1 (2016): 27-44. Dostupno na: https://hrcak.srce.hr/154692

118. Petak I. Klimatske promjene i njihov utjecaj na turizam Republike Hrvatske. Diplomski rad. Rijeka: Fakultet za menadžment u turizmu i ugostiteljstvu, Sveučilište u Rijeci, 2016. Dostupno na: https://zir.nsk.hr/islandora/ object/fthm\%3A120

119. Mohorović M. Utjecaj klime na odvijanje turizma na prostoru Istarske županije. Diplomski rad. Rijeka: Fakultet za menadžment u turizmu i ugostiteljstvu, Sveučilište u Rijeci, 2017. Dostupno na: https://urn.nsk.hr/ urn:nbn:hr:191:847497

120. Šverko Grdić Z, Špoljarić T. Utjecaj klimatskih promjena na turističke tijekove - primjer Republike Hrvatske. Zbornik Veleučilišta u Rijeci 6.1 (2018): 51-66. Dostupno na: https://hrcak.srce.hr/file/294308

121. Europska komisija. Eurobarometer - Special Eurobarometer 459. Climate change. Bruxelles: Europska komisija, 2017. Dostupno na: https://ec.europa.eu/clima/sites/ clima/files/support/docs/report_2017_en.pdf

122. Wall G. The tourism industry and its adaptability and vulnerability to climate change. Climate change and tourism-assessment and coping strategies (2007): 5-18. Dostupno na: https://www.researchgate.net/profile/ Krzysztof_Blazejczyk/publication/233759121_Climate_ Change_and_Tourism_Assessment_and_Coping_Strategies/links/02bfe50e47c21c673a000000.pdf\#page=5

123. Smit B, et al. An anatomy of adaptation to climate change and variability. Climatic Change 45. (2000): 223. Dostupno na: https://doi.org/10.1023/A:1005661622966

124. Smit B, Wandel J. Adaptation, adaptive capacity and vulnerability. Global environmental change 16.3 (2006): 282-292. Dostupno na: https://doi.org/10.1016/j.gloenvcha.2006.03.008

125. Belle N, Bramwell B. Climate change and small island tourism: Policy maker and industry perspectives in Barbados. Journal of travel research 44.1 (2005): 32-41. Dostupno na: https://doi.org/10.1177\%2F0047287505276589

126. Munk Klint L, et al. Dive tourism in Luganville, Vanuatu: Shocks, stressors, and vulnerability to climate change. Tourism in Marine Environments 8.1-2 (2012): 91-109. Dostupno na: https://doi.org/10.3727/1544273 12X13262430524225

127. Frey N, George R. Responsible tourism management: The missing link between business owners' attitudes and behaviour in the Cape Town tourism industry. Tourism management 31.5 (2010): 621-628. Dostupno na: https://doi.org/10.1016/j.tourman.2009.06.017 
INTERINFLUENCE BETWEEN CLIMATE CHANGE AND TOURISM INDUSTRY A NARRATIVE REVIEW

\section{Abstract}

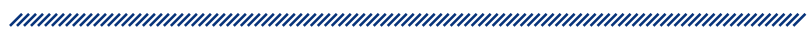

Tourism is one of the fastest growing global economic activities and plays a significant role in national and local economies.

Global climate change, as well as sustainable development through socially and environmentally responsible tourism business, is a current field of research for only a small number of scientists worldwide. There is a lack of broader interest, although an expert group gathered around the International Panel on Climate Change (IPCC) in the mid-1990s of the 20th century confirmed "with almost complete certainty that human activities are the dominant cause of global warming, leading to multiple manifestations of climate change." In this way, climate change is no longer the subject of academic research only, but taking into account all other environmental problems, climate change has currently become the greatest challenge and threat to the survival of human civilization, with numerous consequences and a very wide impact on almost all aspects of human life. Climate change undoubtedly also affects the economy, social aspects and relationships in society, and only partly, though very importantly, tourism as an economic branch. There is a two-way relationship between tourism and climate change. On the one hand, tourism largely depends on climate elements such as temperature, precipitation and hours of insolation in the day, that is, on the climate as a whole as an important factor. On the other hand, tourism as a whole, especially transport related to tourist arrivals and departures and tourist accommodation per se, contribute significantly to global warming through greenhouse gas emissions and a significant carbon footprint of tourism. The effects of climate change lead, among other things, to increased risk of floods and droughts, melting of glaciers, rising sea levels, loss of biodiversity, various threats to human health, changing relationships in the social sphere, as well as causing significant damage to all economic activities. Given the extremely high contribution of tourism to the overall gross domestic product of national economies at the same time, any impact of climate change on tourism can have very important economic and development implications. This is very important in Croatia, where tourism forms the backbone of the economy. Great efforts are being made globally and nationally to mitigate the effects of climate change and to plan and take measures to prevent further adverse effects that may be irreversible in the future. Mitigating the interplay of tourism and climate change only seems to depend primarily on technological change, but above all it also significantly depends on economic, political, social and structural change.

Keywords: climate, climate change, global warming, tourism, hotels 